\title{
0
}

\section{RUBIES AND FANCY SAPPHIRES From VIETNAM}

By Robert E. Kane, Shane F. McClure, Robert C. Kammerling, Nguyen Dang Khoa, Carlo Mora, Saverio Repetto, Nguyen Duc Khai, and John I. Koivula

Gem-quality rubies and pink to purple sapphires are being recovered from the Luc Yen and Quy Chau mining regions of Vietnam. This article briefly reviews the history and geology of these areas, as well as the mining methods used. The gemological characteristics of more than 100 of these stones are described in detail. The most notable internal features are blue color zones, swirl-tike and angular growth features, bluish "clouds," and inclusions of rod-like calcite and pyrrhotite as well as the rare mineral nordstrandite.

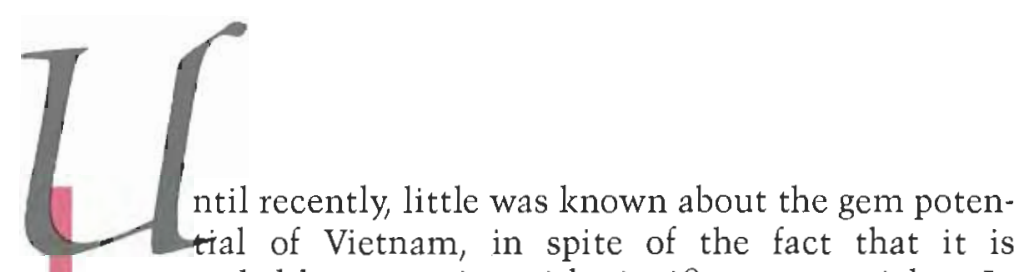
surrounded by countries with significant gem riches. In 1983, however, corundum was reported near the towns of Ham Yen and An Phu, north of Hanoi. Major exploration began in 1987, when geologists brought to the attention of the local government their discovery of rubies near the town of Luc Yen, $28 \mathrm{~km}$ west of Ham Yen, in Yen Bai (formerly Hoang Lien Son) Province.

In a five-month period, from November 1989 through March 1990, one deposit in the Luc Yen district produced more than three million carats of rough pink sapphire and ruby. Several other deposits are currently being worked in this gem-rich district. According to various trade sources, the finest rubies from this locality rival the finest stones from Myanmar (formerly Burma; see, e.g., "Vietnam Claims Major Ruby Find," 1990; Hughes and Sersen, 1991; and Weldon, 1991). In December of 1990, rudimentary mining operations began at Quy Chau in Nghe An (formerly Nghe Tinh) Province, south of Hanoi. Stones examined thus far from this latter deposit compare favorably with those mined at Luc Yen (figure 1).

Two of the authors, Messrs. Khai and Khoa, have been involved in the geologic study of the gem deposits of Vietnam and the marketing of the stones recovered. Messrs. Mora and Repetto are participating in a joint venture between the Italian firm Tecno-Resource (a subsidiary of FIMO Inc., of Switzerland) and the Vietnamese government to establish a cutting operation and gemological laboratory in Vietnam. They provided GIA with numerous samples of rubies and pink to purple sapphires obtained in Vietnam, which formed the basis of the current research. This article reviews the Luc Yen and Quy Chau mining regions, and provides a gemological characterization of the rubies and fancy sapphires found there.

Vietnamese geologists believe that there is consider- 


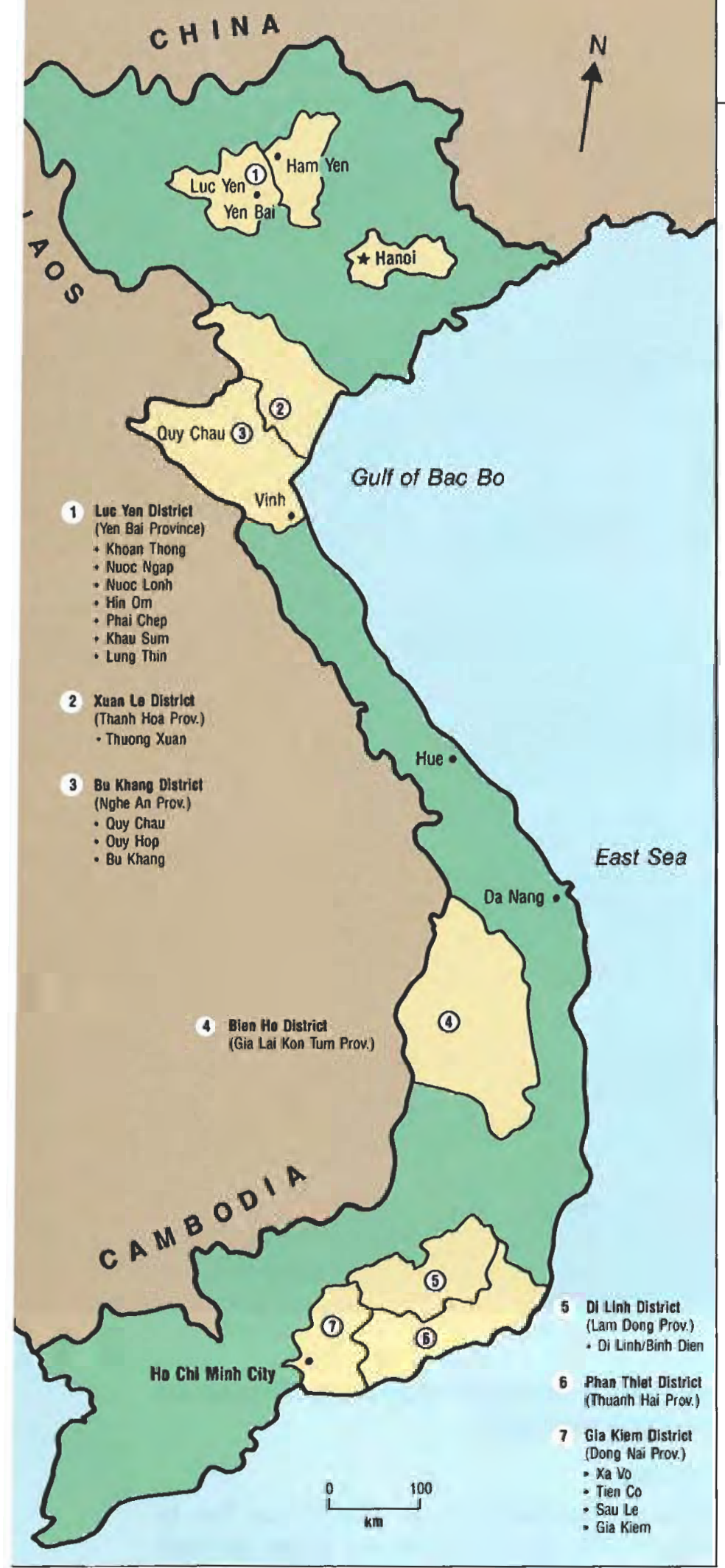

Figure 2. This map of Vietnam shows the major localities where rubies are currently being mined (together with spinels, garnets, and some tourmaline), as well as known deposits of blue sapphire and other gem materials. The numbers are keyed to specific localities discussed in the text and listed in the key. Artwork by Carol Silver. deposit at Luc Yen. In November 1989, the B. H. Mining/Vinagemco joint venture opened Vietnam's first commercial gem-mining operation. During the period November 1989 through March 1990 , they recovered approximately $244 \mathrm{~kg}$ of potentially gem-quality corundum. At the height of exploitation at Khoan Thong, there were approximately 70 workers. Since March 1990, however, management problems have led to reconsideration of the joint venture and organized mining has come to a virtual halt. In October 1990, a law was enacted that prohibits foreigners from traveling to the mine area.

Also in 1988, Savimex Cie. of Ho Chi Minh City entered into a joint venture, called Savitech, with the Italian firm Tecno-Resource to develop a faceting industry and gemological laboratory in Vietnam. Originally, this joint venture was set up to analyze and facet rough material from the Bo Pailin ruby and sapphire district in Kampuchea (Cambodia); however, heavy fighting in that region has made the supply of such material very erratic. With the successful mining of rubies and fancy sapphires at Luc Yen-and, more recently, Quy Chau-Savitech became involved in the evaluation and cutting of this material as well.

Although mining in the Luc Yen area is officially under the direct control of the Yen Bai Province People's Committee, most of the activity is by local "smugglers." During some periods, thousands of these independent miners have swarmed over the area. It is likely, then, that actual production considerably exceeds official figures.

Mining is known to have started at Quy Chau as early as December 1990, by local peasants. In July 1991, authorities of the Nghe An Province People's Committee established four mining enterprises to control and exploit gem deposits in the Quy Chau area. As at Luc Yen, the number of official workers is relatively small -50 in this case - but during some periods more than 10,000 independent miners, from all over Vietnam, have worked illegally throughout the area. Although the most recent statistics on official production at Quy Chau are the equivalent of US $\$ 20,000$ per month, actual production undoubtedly is several times larger.

\section{LUC YEN}

Location and Access. The Luc Yen mining region is located approximately $270 \mathrm{~km}$ northwest of Hanoi, just $75 \mathrm{~km}$ from the border with China. 


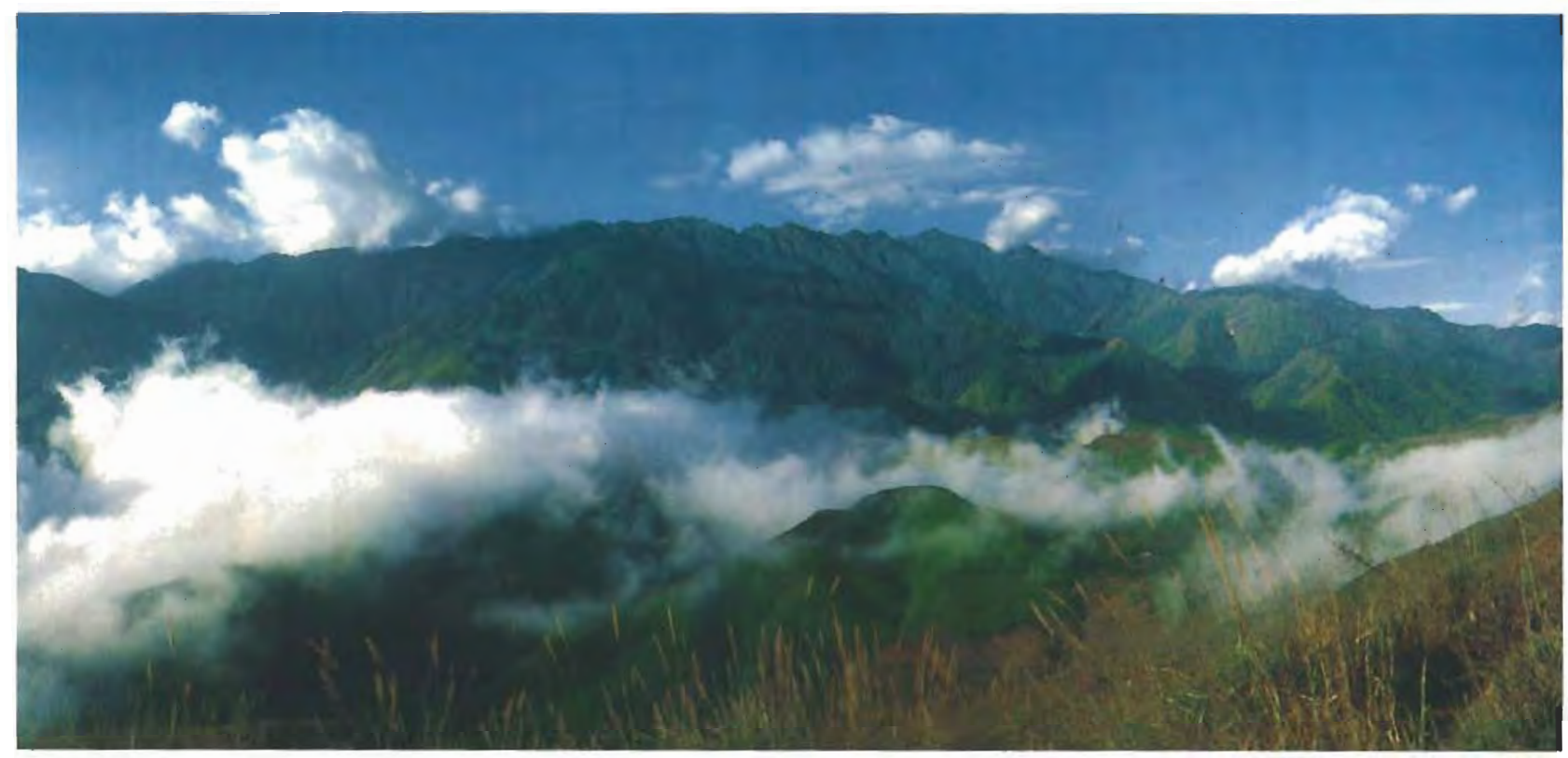

Figure 3. Rubies are being mined in the valleys and foothills of the imposing Bac Bo Mountains of northem Vietnam.

Seven deposits are currently being worked in the area-at Khoan Thong, Nuoc Ngap, Nuoc Lanh, Hin Om, Phai Chep, Khau Sum, and Lung Thinall within $8 \mathrm{~km}$ south, southeast, and southsouthwest of the town of Luc Yen (figure 2). To date, the rubies and fancy sapphires have been found in secondary, largely alluvial deposits in the lush tropical valleys and foothills of the Bac Bo (previously, Tonkin) Mountains (figure 3). For the most part, roads in the region are not paved, but the area is readily accessible from Hanoi except during the rainy season (approximately May to November), when the mud becomes too deep to allow passage by vehicle.

Geology and Description of the Gem-Bearing Deposits. Exploration has identified rubies and fancy sapphires in secondary deposits that occur over a surface area of approximately $50 \mathrm{~km}^{2}$, with evidence of an even larger area of some $300 \mathrm{~km}^{2}$. The deposits are located in small valleys within the Bac Bo Mountain Range, on the sides of surrounding hills, in rice paddies at the base of the mountains, and along the rivers that cross the area.

The placer deposits are found in Quaternary sediments lying in a karst-like terrain of depressions and valley terraces within a $130 \mathrm{~km} \times 2-5$ $\mathrm{km}$ northeast-southwest trending belt of Upper Proterozoic-Lower Cambrian marbleized limestones and crystalline schists and quartzites (see figure 4). The gem-bearing valleys are often nar- row, small depressions ranging from 0.5 to $7.0 \mathrm{~km}^{2}$ but most commonly $2-3 \mathrm{~km}^{2}$. They are part of the Vietbac formation (Phan Cu Tien, 1989). It has been suggested that the mineralized marble belt in which the Luc Yen stones have been found is similar to the geologic conditions in which rubies occur in the Mogok area of Myanmar and the Hunza Valley of Pakistan (Bank and Henn, 1990; Henn and Bank, 1991; H. Hänni, as reported in Koivula and Kammerling, 1990). The gem-bearing sedimentary beds average $2-3 \mathrm{~m}$ thick; the overburden ranges from less than a meter in some areas to as deep as $5 \mathrm{~m}$ in others. To date, no corundum has been recovered in situ, but local geologists have found some corundum samples still embedded in matrix (figure 5). Local geologists believe that the rubies are formed in association with pegmatites.

Associated gem minerals include red, pink, and pale blue spinels /which may represent from $70 \%$ to $90 \%$ of the gem material in a particular site), as well as potentially gem-quality (but small) yellow and green tourmalines and garnets. All of the corundum found here to date has been pink to purple to red.

Mining Methods. Open-pit mining is the dominant method used. Several pits, $1.5-3 \mathrm{~m}$ in diameter and 3-7 $\mathrm{m}$ deep, have been dug using backhoes and by hand throughout the Luc Yen district. In the most sophisticated operation, at Khoan Thong, the 


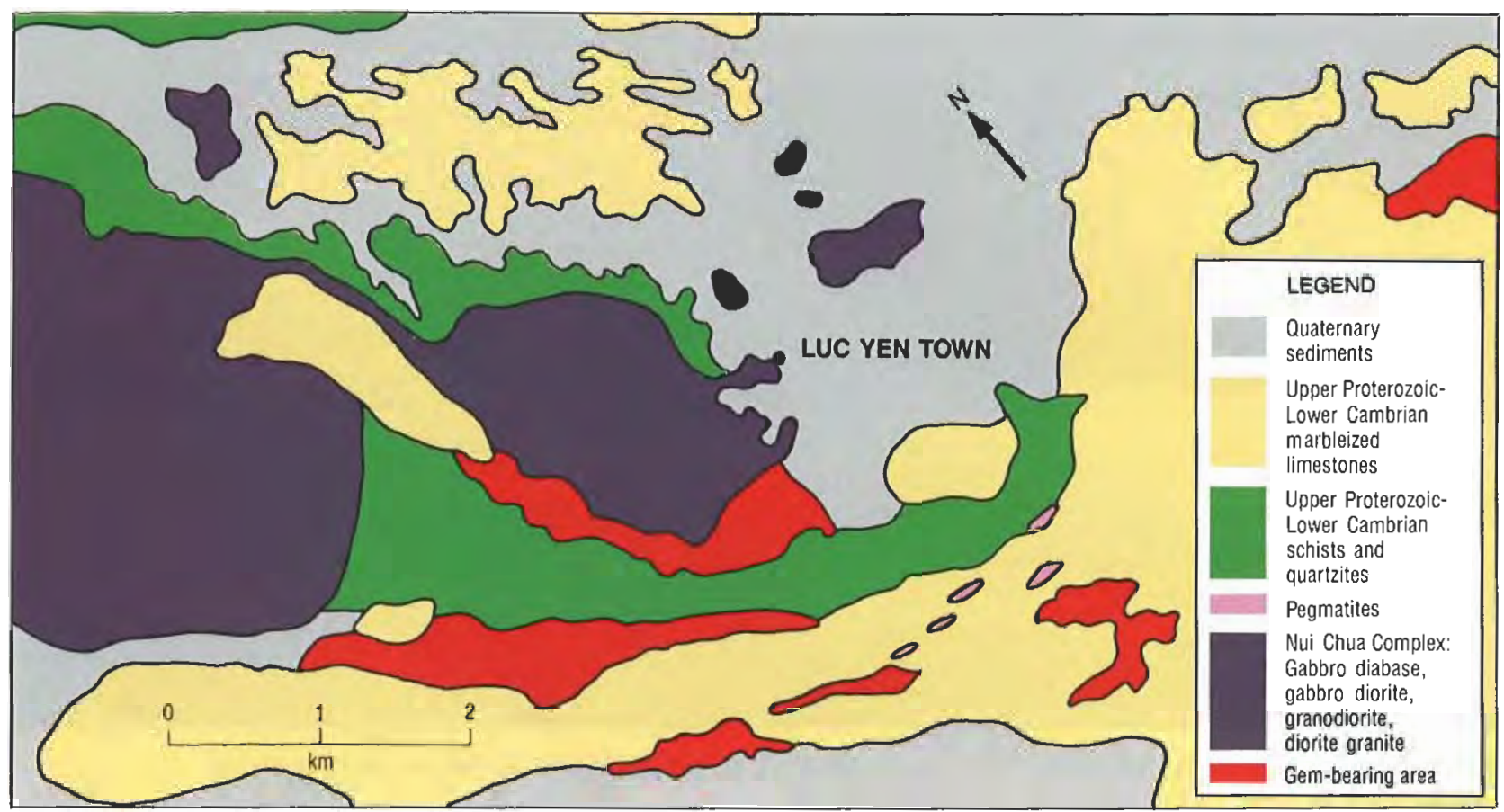

Figure 4. This geologic map of the Luc Yen region shows the areas where gems have been found in Quaternary sediments lying in karst-like depressions in a northeast-southwest trending belt of Upper Proterozoic-Lower Cambrian marbleized limestones, schists, and quartzites. Map prepared by N. D. Khoa; artwork by Carol Silver.

miners would spray the dry pits with water cannons and then pump the resulting mud into an inclined wood channel that leads to a large jig. In this sluice-type arrangement (figure 6), the water softens the earth and removes the dirt, while the largest rocks are removed by hand. At the jig, the corundum is sorted from the gravels by a combination of vibrating action and specific gravity. The

Figure 5. This corundum crystal in syenite matrix was found in the Luc Yen area of Vietnam. Photo by N. D. Khoa.

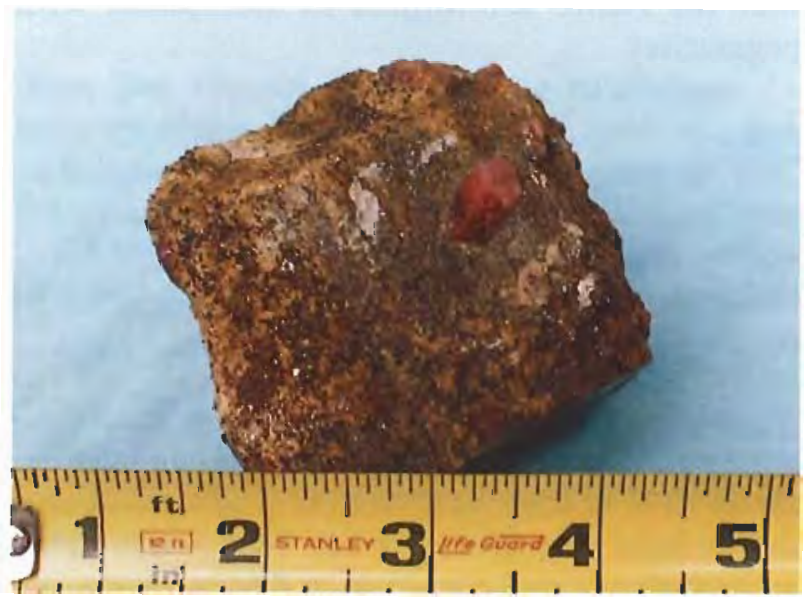

last step is to separate the corundum from the remaining concentrate by hand. Gem recovery at Khoan Thong has been very high, averaging 19.6 grams per cubic meter.

Distribution of the final gem production is ostensibly controlled by the provincial government; however, local miners and dealers commonly travel to Hanoi and other major cities to sell their rough. To date, it appears that large amounts of this material have not arrived on the world gem markets (Weldon, 1991). An auction widely reported in the trade press has been delayed three times, with no date confirmed to the authors' knowledge as of October 1991 ("Ruby Auction in Vietnam," 1990; Federman, 1991; "Viets Delay Ruby Sales until . ..," 1991; "No Date for Ruby Auction in Vietnam," 1991; "Long-Awaited Auction May Come Off in July," 1991).

\section{QUY CHAU}

Location and Access. Late last year, mining was begun in northern Nghe An Province (again, see figure 2), near the village of Quy Chau. The potential ruby-bearing area covers approximately $400 \mathrm{~km}^{2}$. The Quy Chau mining district is located about $120 \mathrm{~km}$ by road northwest of the city of Vinh, the administrative center of Nghe An Prov- 
ince, and $36 \mathrm{~km}$ northwest of the district center of Nghia Dan. As many as 10,000 miners have descended on the area during periods of peak mining, from all over Vietnam (figure 7).

The gem-bearing region is a mountainous area that reaches heights of $1,058 \mathrm{~m}$ near the villages of Quy Chau and Quy Hop. However, the actual gem deposits are concentrated in narrow valleys and along streams that form upper tributaries of the Hieu River. As at Luc Yen, mining is difficult in this tropical area during the May to November rainy season.

Geology and Occurrence. The Quy Chau deposits lie within the $\mathrm{Bu}$ Khang ruby zone of central Vietnam; geologists report that ruby mineralization covers approximately $2,000 \mathrm{~km}^{2}$ near $\mathrm{Bu}$ Khang Mountain, with, as mentioned above, a 400 $\mathrm{km}^{2}$ zone that appears to have the best rubybearing potential. The rubies have been found associated with tin minerals in Quaternary sediments. Detailed geologic study has not yet been conducted on the Quy Chau area.

The deposits near the village of Quy Chau, where the best rubies in the area have been found thus far, appear to be eluvial. Smaller, less transparent gems have been found in alluvial deposits near Quy Hop, south of Quy Chau.

Mining Methods. To date, mining at Quy Chau has been very primitive. Although some stones have

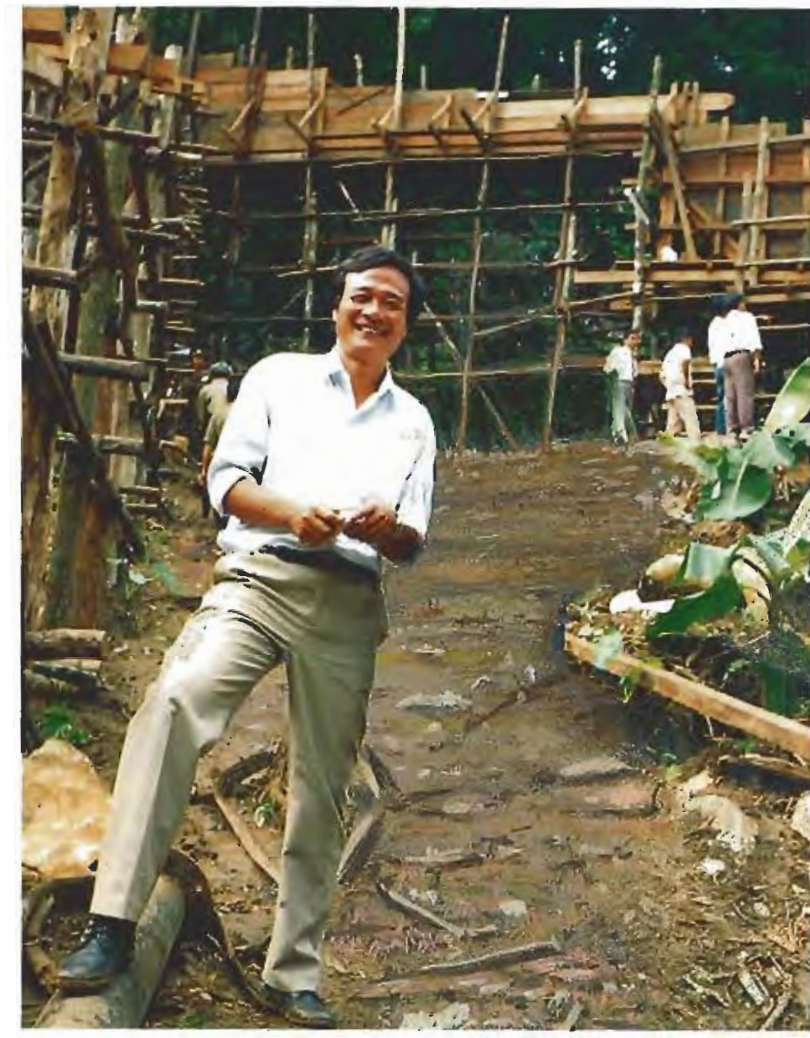

Figure 6. The Khoan Thong mining operation has been the most sophisticated to date in the Luc Yen area. The sluice carries the gem-bearing gravels, mixed with water, to a jig, where they are sorted. Photo by C. Mora.

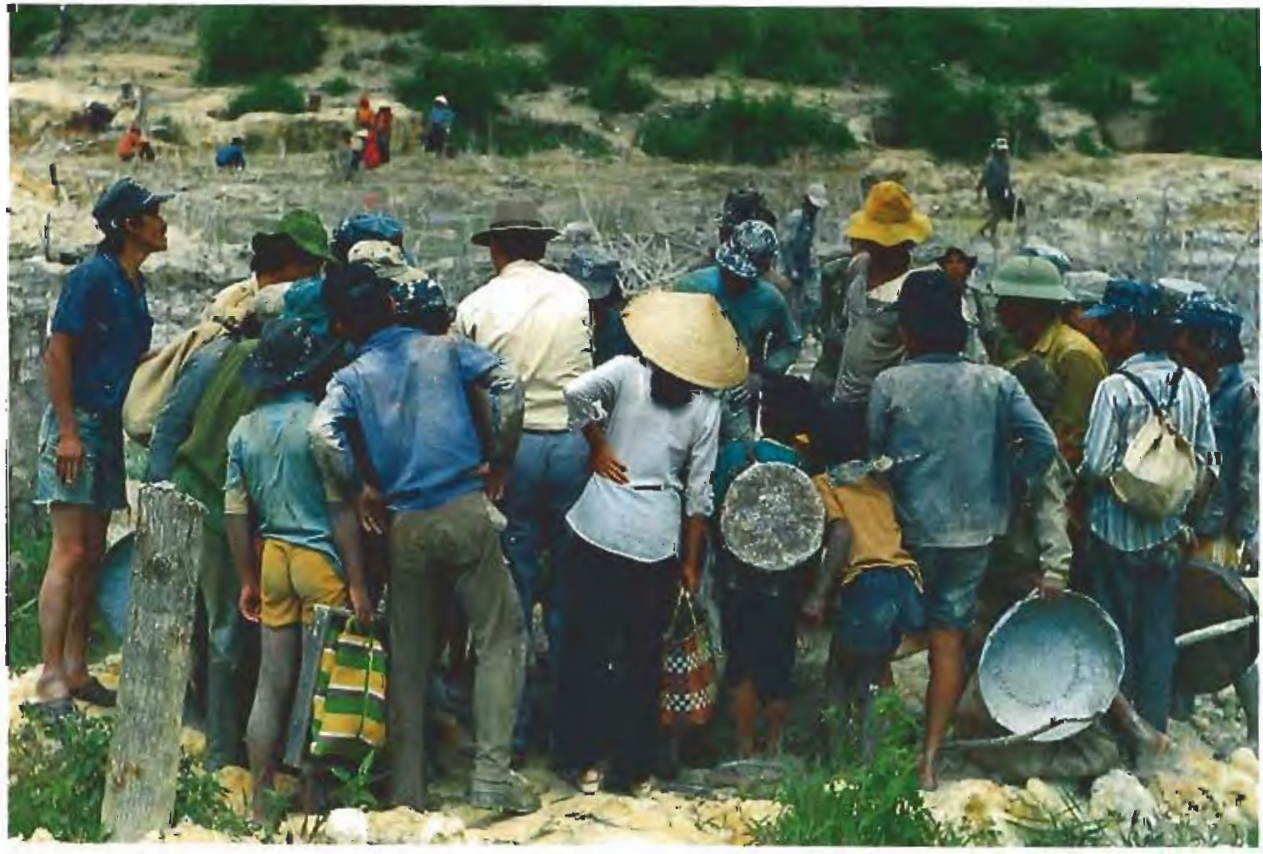

Figure 7. At the height of activity in 1991, "independent" miners descended on the Quy Chau area from all over Vietnam in search of rubies and other gems. Photo by C. Mora. 


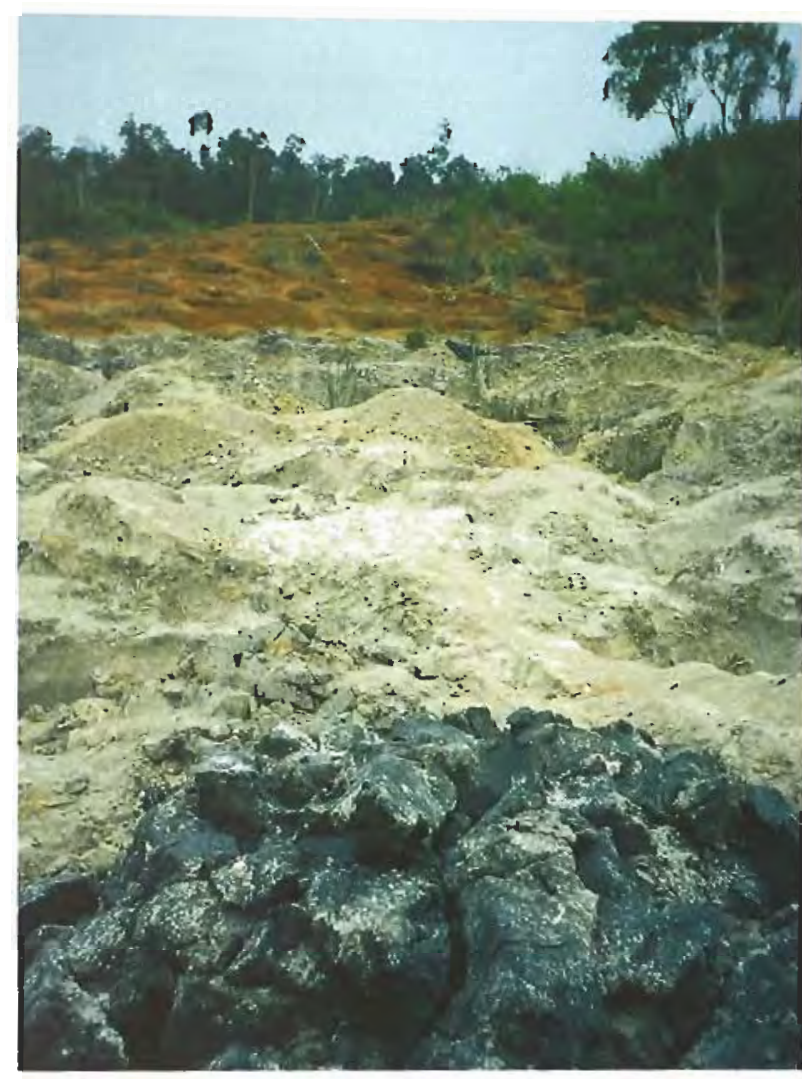

Figure 8. In many parts of the Quy Chau rubybearing district, the gem-bearing gravels can be reached only by removing layers of clay and $\mathrm{ka}$ olin. Here a pile of wet gray kaolin (foreground) that has just been removed lies next to mounds of dry white kaolin. In the back can be seen the clay-like soil that covers the surface of the region. Photo by C. Mora.

Figure 9. At Quy Chau, pits may be dug as deep as $7 \mathrm{~m}$ to reach the gem-bearing gravels, and are reinforced with bamboo poles. Photo by C. Mora.

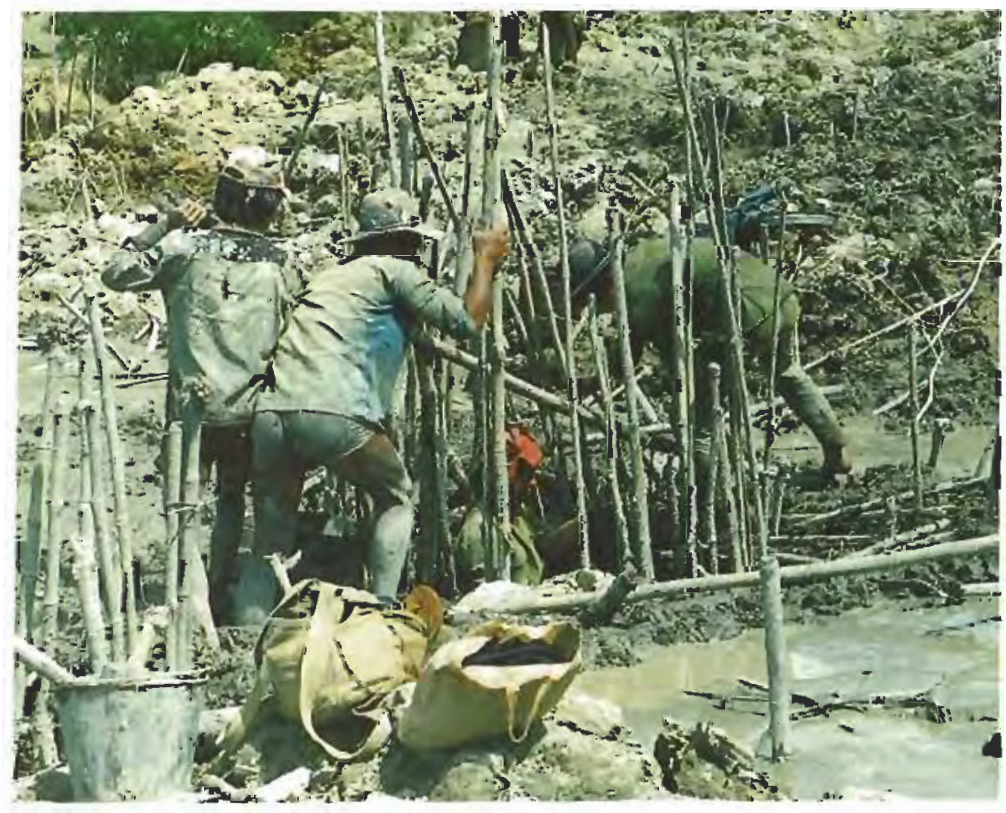

been found literally on the surface of the ground and in streams, the miners usually must first remove layers of kaolin and clay-like soil to reach the corundum-bearing gravels (figure 8). Pitsanywhere from one to several meters round or even square-are dug in the relatively soft overburden approximately 3 to $7 \mathrm{~m}$ deep to reach the gembearing layer. The pits are reinforced with bamboo canes (figure 9). Flooding is a constant problem, but thus far we have not seen pumps used. The gembearing gravel layer has been observed to be anywhere from approximately 1 to $8 \mathrm{~m}$ thick.

Once the gravels are removed, they are washed and sorted by hand (figure 10). In addition to ruby, miners have found pink and yellow sapphire, various colors of spinel, and some garnet. As at Luc Yen, spinel is the most common gem material found. Although the provincial government is holding monthly auctions of the material produced in its operations, to date most of the rough has been sold outside of legal government channels: at the mining area, in towns throughout the province, especially the city of Vinh, and in Hanoi and Ho Chi Minh City.

\section{DESCRIPTION OF THE RUBIES AND FANCY SAPPHIRES}

Luc Yen. Most of the gem-quality material ranges from 2 to $6 \mathrm{~mm}$ long. Although large pieces of rough are rare, they have been known to exceed 20 ct. Crystals from Luc Yen exhibit a regular prismatic shape typical of corundum (figure 11). Most of the rough is moderately worn, but some of the crystals found to date show unusually sharp faces, which suggests that they have not traveled far from their original source. In addition, at least one (inclined axis) twin crystal has been identified (E. Fritsch, pers. comm., 1991). The stones range in color from medium light to medium pink and medium to dark red, purplish red, and pinkish purple.

Quy Chau. Because this deposit is relatively new, little can be generalized about the rubies and fancy sapphires found there. Both extremely worn and relatively well-formed crystals have been seen to date. Our examination of the rough seen thus far indicates that in general these stones appear to be less included and, therefore, more transparent than much of the material from Luc Yen. One of the authors (NDK) has seen pieces of rough as large as $10 \mathrm{ct}$, and believes that this deposit could yield 


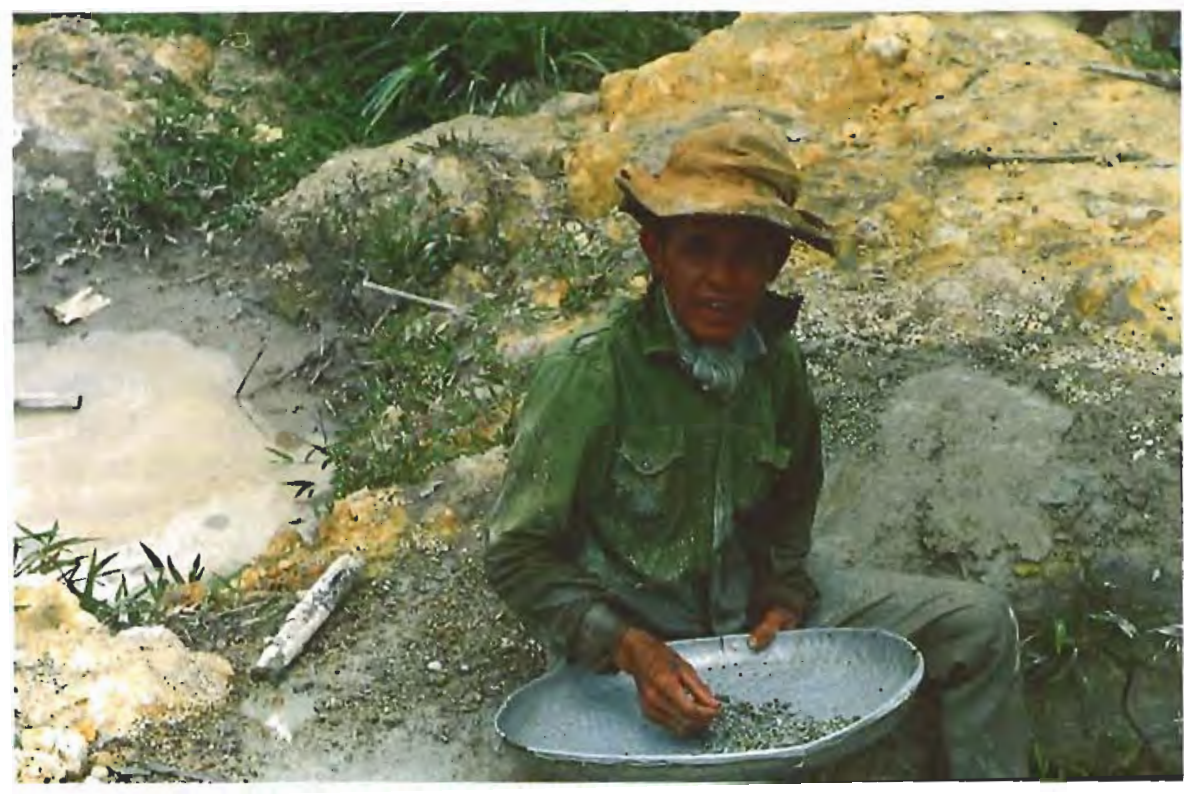

Figure 10. For the most part at Quy Chau, the miners wash the gravels by hand using rudimentary "pans" in their search for rubies and other gem mate. rials. Photo by C. Mora.

stones that are larger on average than Luc Yen. The material ranges from near colorless to red; most is pink to a lower saturation of red.

\section{GEMOLOGICAL CHARACTERISTICS OF SOME RÜBIES AND PINK TO PURPLE SAPPHIRES FROM VIETNAM}

Four of the authors (REK, SFM, RCK, and JIK) examined more than 100 faceted rubies and pink to purple sapphires, ranging in weight from 0.17 to $1.94 \mathrm{ct}$, that were reported to be from the Luc Yen and Quy Chau mining areas in Vietnam. All of the 124 research stones were obtained by FIMO representatives in Vietnam from government sources, from independent miners in the Luc Yen and Quy Chau areas, and from "dealers" in Hanoi and Ho Chi Minh City. Routine gemological testing established that out of the 124 faceted samples that were provided to these investigators, one was a flamefusion synthetic ruby, two were purple-red almandite garnets, and nine were natural spinels |ranging in color from pink to orangy red); thus leaving 112 natural rubies and fancy sapphires. This was not the first time the authors had seen flame-fusion synthetic rubies being represented as natural Vietnamese stones and reports in the trade press indicate that this is happening with some frequency (e.g., "Synthetic Found Mixed with Rough Ruby" 1991; Weidinger, 1991).

The remaining test samples, which were confirmed to be natural corundum, exhibited many characteristics that are typical of natural rubies and pink to purple sapphires from various geo-
Figure 11. A number of relatively well formed crystals (here, $4.75 \mathrm{~cm}$ long) have been found at Luc Yen. Photo (C) GIA and Tino Hammid.

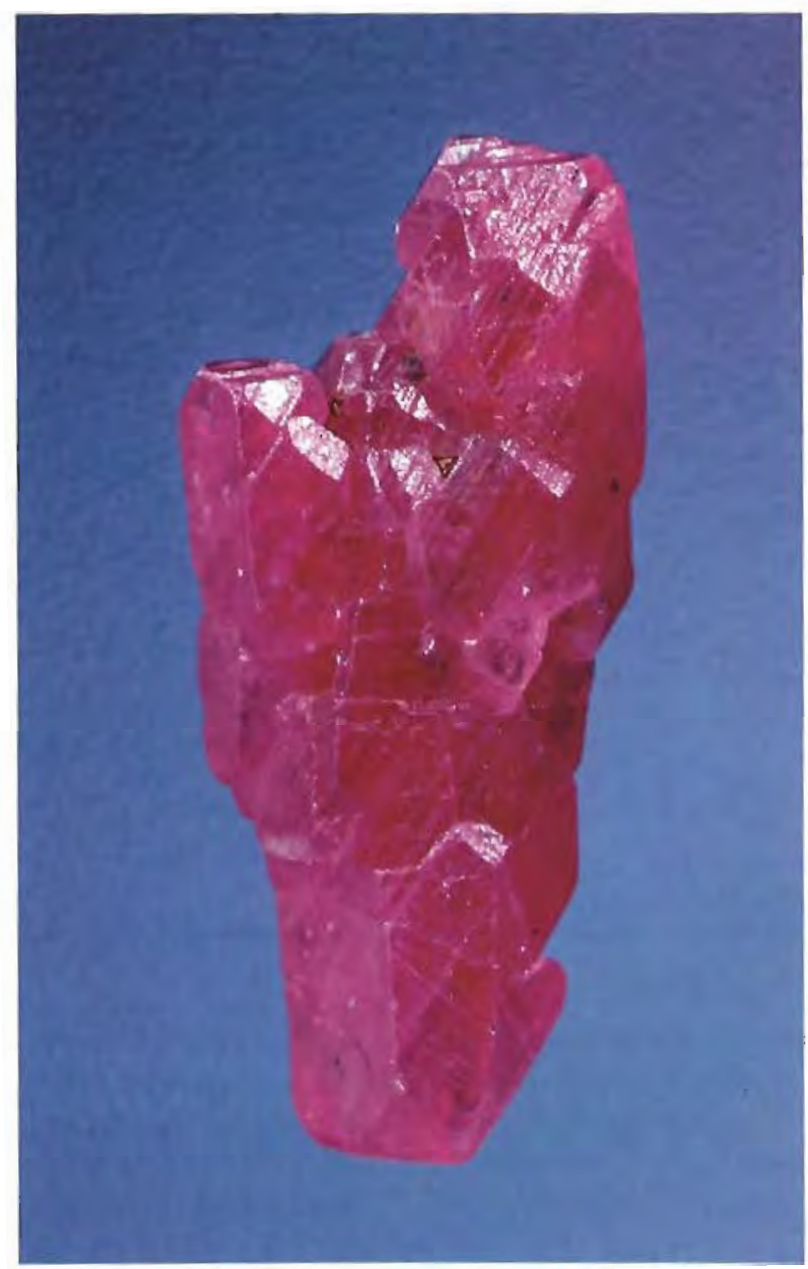


TABLE 1. Gemological characteristics of rubies and pink to purple sapphires from the Luc Yen and Quy Chau gem districts of Vietnam.

\begin{tabular}{|c|c|c|}
\hline Property & $\begin{array}{l}\text { No. } \\
\text { samples }\end{array}$ & Observations \\
\hline Color & 112 & $\begin{array}{l}\text { Moderate to highly saturated } \\
\text { purplish red to purplish pink } \\
\text { through reddish purple to pinkish } \\
\text { purple in medium light to dark } \\
\text { tones }\end{array}$ \\
\hline Clarity & 112 & $\begin{array}{l}\text { Most heavily included; few "eye } \\
\text { clean" }\end{array}$ \\
\hline $\begin{array}{l}\text { Refractive } \\
\text { indices }\end{array}$ & 55 & $\begin{array}{l}\text { Most within the range: } \\
e=1.759-1.762 \\
0=1.768-1.770\end{array}$ \\
\hline Birefringence & 55 & $0.008-0.009$ \\
\hline $\begin{array}{l}\text { Optic } \\
\text { character }\end{array}$ & 55 & Uniaxial negative \\
\hline $\begin{array}{l}\text { Specific } \\
\text { gravity }\end{array}$ & $\begin{array}{l}9 \text { cut } \\
3 \times 1 \mathrm{~s}\end{array}$ & $\begin{array}{l}3.97-4.00 \\
3.99-4.00\end{array}$ \\
\hline Pleochroism & 43 & $\begin{array}{l}\text { Moderate to strong dichroism; } \\
\text { usually reddish purple to purplish } \\
\text { red parallel to c-axis and orangy } \\
\text { pink to orange-red perpendicular to } \\
\text { c; colors vary slightly with body } \\
\text { color of stone }\end{array}$ \\
\hline $\begin{array}{l}\text { U.V. } \\
\text { luminescence }\end{array}$ & 112 & $\begin{array}{l}\text { Strongest reactions in stones of } \\
\text { medium to high saturations and } \\
\text { medium to dark tones of pink to } \\
\text { red; weaker reactions in lighter and } \\
\text { or more purplish stones; weakest } \\
\text { reactions in stones with an orange } \\
\text { component }\end{array}$ \\
\hline Long-wave & & $\begin{array}{l}\text { Weak to very strong red to orangy } \\
\text { red }\end{array}$ \\
\hline Short-wave & & Similar but weaker \\
\hline $\begin{array}{l}\text { Optical } \\
\text { absorption } \\
\text { spectrum } \\
(\mathrm{nm})\end{array}$ & 55 & $\begin{array}{l}468.5 \text { (sharp, narrow) } \\
475 \text { (extremely weak) } \\
476.5 \text { (sharp, narrow) doublet } \\
659.2 \text { (faint, narrow) } \\
668 \text { (faint, narrow) } \\
692.8 \text { (distinct, narrow) } \\
694.2 \text { (distinct, narrow) }^{a}\end{array}$ \\
\hline $\begin{array}{l}\text { Internal } \\
\text { features }\end{array}$ & 112 & $\begin{array}{l}\text { Distinct blue color zones, swirled } \\
\text { growth features, laminated twinning } \\
\text { planes, clouds of minute particles, } \\
\text { orange-stained fractures, and solid } \\
\text { inclusions of: calcite, apatite, } \\
\text { nordstrandite, pyrrhotite, } \\
\text { phlogopite, and rutile }\end{array}$ \\
\hline
\end{tabular}

aMay appear as a single bright (emission) line.

graphic localities, in addition to some microscopic features that are distinctly different from any that we have observed thus far in natural rubies and fancy sapphires from other sources. Table 1 summarizes the gemological characteristics determined in this study for rubies and pink to purple sapphires from the Quy Chau and Luc Yen areas of Vietnam.

Visual Appearance. The most noticeable feature of many of the stones examined in this study is the similarity in color to rubies and pink sapphires from Mogok, although some of the stones are more purple than what is commonly thought of as "Burmese" color. These colors range from moderate to high saturations of purplish red to purplish pink through reddish purple to pinkish purple in medium light to dark tones (figure 12). A significant number of the sample stones also exhibited eye-visible blue color zones, giving them an uneven color appearance.

The clarity of the stones examined was relatively low. Very few were eye clean and some were so included that they were uniformly translucent. In fact, some stones appeared to be orangy red or orangy pink due to the presence of large orangestained fractures, which are discussed later in the text. To date, the material examined by Savitech in Ho Chi Minh City has been $64 \%$ carving quality, $30 \%$ cabochon quality, and $6 \%$ faceting quality.

Refractive Indices and Birefringence. We obtained refractive index values with a GEM Duplex II refractometer and a near-monochromatic light source that approximates sodium vapor. The observed refractive index and birefringence values (see table 1) are within the ranges previously reported for rubies and pink to purple sapphires in general (Webster, 1983; Liddicoat, 1989), as well as those reported specifically for Vietnamese material (Bank and Henn, 1990; Henn and Bank, 1990, 1991; Brown and Chill, 1991; Koivula and Kammerling, 1991). One stone had values of 1.764-1.773, outside the normal range. However, this variation has been reported in corundums from other sources (Arem, 1987).

Specific Gravity. The specific gravity values for nine faceted stones $(0.71-1.94 \mathrm{ct})$ and three pieces of transparent to translucent rough $(7.10,8.30$, and $14.52 \mathrm{ct})$ were determined by the hydrostatic weighing method. The observed values agree with those previously reported in the literature for corundums from Vietnam and localities worldwide.

Polariscope Reaction. Surprisingly, it was difficult - and in some cases, impossible-to resolve an 


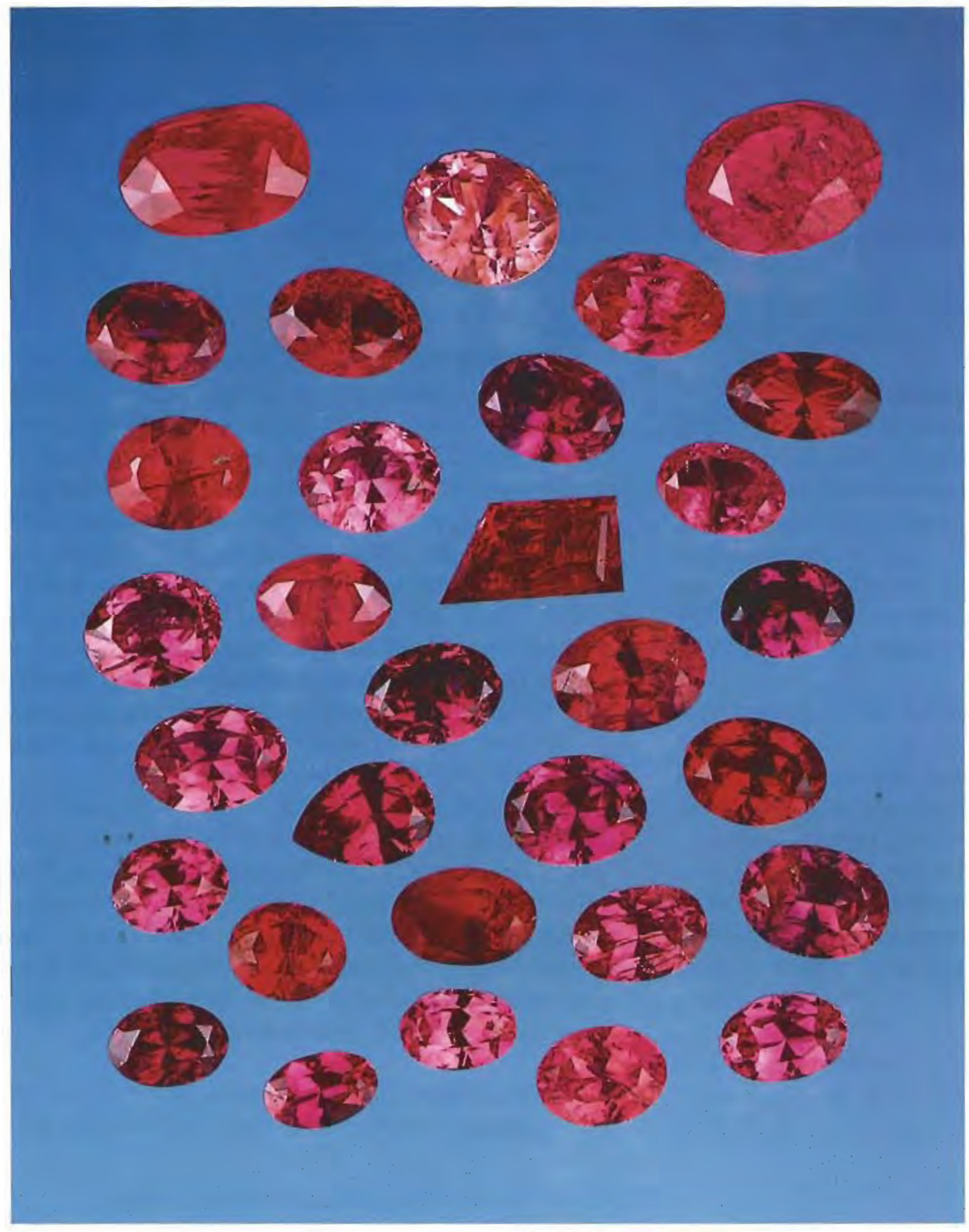

Figure 12, Rubies and fancy sapphires have been found in a broad range of colors and saturations at the Luc Yen and Quy Chau deposits in Vietnam. Note that the stone at the top center appears orangy because of the presence of large orange-stained feathers. These stones range from 0.17 to 1.94 ct. Photo by Shane McClure.

interference optic figure in the polariscope for many of the stones so examined with a standard condensing lens. This is believed to be due to the twinning structures that many of these stones exhibit (see "Growth Features" below).

Pleochroism. Forty-three of the Vietnamese stones were examined using a calcite dichroscope. The reactions observed are typical for rubies and pink to purple sapphires from other localities.

Reaction to Ultraviolet Radiation. All 112 Vietnamese corundums were exposed to long-wave (366 nm) and short-wave (254 nm) ultraviolet radiation. Stones of lower saturations and darker tones tended to be correspondingly weaker in fluorescence, as were stones of predominantly purple hues, possibly due to the presence of nonfluorescing blue zones and/or quenching by iron.

Approximately $40 \%$ of the stones exhibited very small to large zones that were completely inert to both wavelengths. These nonfluorescing areas correspond directly to the blue color zones in these stones (as is discussed below and was noted previously in Koivula and Kammerling, 1991).

Absorption Spectra. Visible-light absorption spectra were obtained with a Beck prism spectroscope 
mounted on a GIA GEM spectroscope base unit. Spectra for the Vietnamese rubies are essentially the same as the diagnostic absorption spectra described by Liddicoat (1989) for natural and synthetic ruby, purple sapphire, and dark "padparadscha" sapphire. The distinct lines at 692.8 $\mathrm{nm}$ and $694.2 \mathrm{~nm}$ often appear as a single bright fluorescent (emission) line, also typical for ruby.

Internal Characteristics. Careful microscopic examination of all 112 samples in this study revealed a wealth of interesting internal features. Some of the most commonly encountered internal features are reminiscent of those found in Burmese rubies, while others are similar to some found in rubies from Thailand. Still others are unlike those we have observed in stones from any other locality and appear at this time to be unique to rubies from Vietnam.

Note that the physical evidence indicates that most of the stones we examined had not been subjected to heat treatment. However, we have received reports that at least some Vietnamese rubies now in the trade have been heat treated (e.g., $\mathrm{R}$. Crowningshield, pers. comm., 1991). It is reasonable to assume that the majority of the material from Vietnam, like ruby from virtually all other localitics, will be heat treated at some point before it reaches the jeweler.

Color Zoning. One of the most notable features of these Vietnamese rubies and pink to purple sapphires is the presence of distinct medium-dark to

Figure 13. Distinct dark blue color zones were a common feature in the Vietnamese corundums examined in this study. Darkfield with shadowing and partially polarized illumination, magnified $35 \times$; photomicrograph by Robert E. Kane.

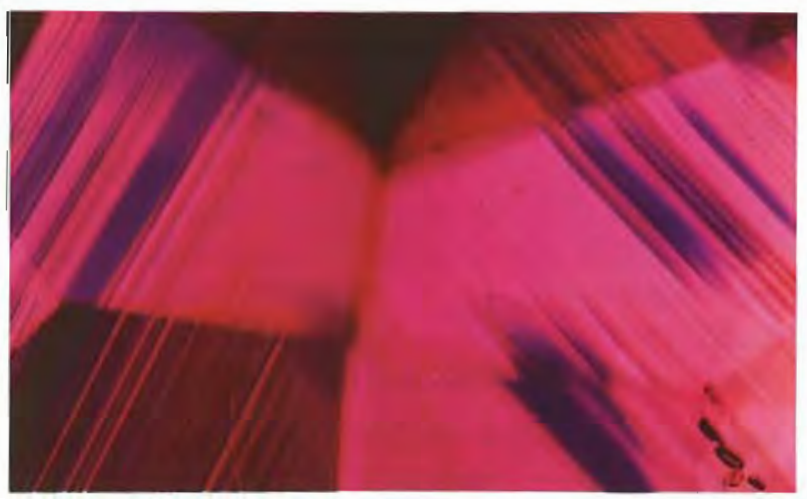

dark blue color zones (figure 13) in most, though not all, of the specimens examined. These zones range in size from large areas to tiny slivers that follow growth planes. All are fairly to extremely well defined with sharp edges and distinct borders. Some consist of uniformly colored areas, whereas others consist of rather distinct, parallel color bands.

The fact that areas of blue zoning were observed in so many of the sample stones implies that such zones are typical of material from Vietnam; their presence has previously been noted in Vietnamese stones examined by other investigators (see, e.g., Brown and Chill, 1991; Hughes and Sersen, 1991; H. Hänni, as quoted in "Vietnam: An Important Potential New Source of Fine Ruby," 1990). They are not unique, however, to Vietnamese stones, having also been observed in some rubies from Jegdalek in Afghanistan (e.g., Bowersox, 1985) and from Nepal (Harding and Scarratt, 1986) as well as, by some of the authors, in pink sapphires from Montana and Sri Lanka.

In addition to the blue zoning, we also observed pink, orangy pink, red, and/or near-colorless zones in many samples (figure 14), as well as yellow zones in a few. In many cases, these color zones are so distinct as to be visible with the unaided eye, although details of the zoning are best seen using magnification in conjunction with immersion in methylene iodide (figure 15).

Growth Features. The stones we examined contain an abundance of irregular, "swirled" growth fea-

Figure 14. Color distribution was very inhomogeneous in the stones examined in this study. Distinct red, pink, and near-colorless zones were common in many forms. Darkfield and shadowing, magnified 25x; photomicrograph by Robert E. Kane.

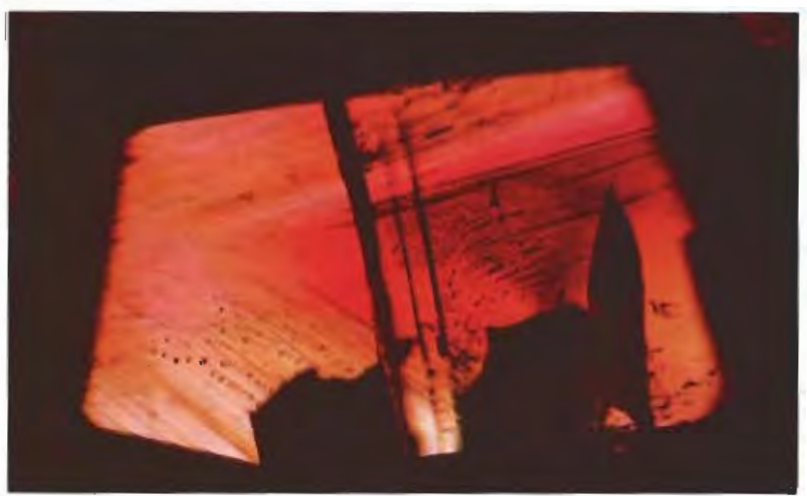




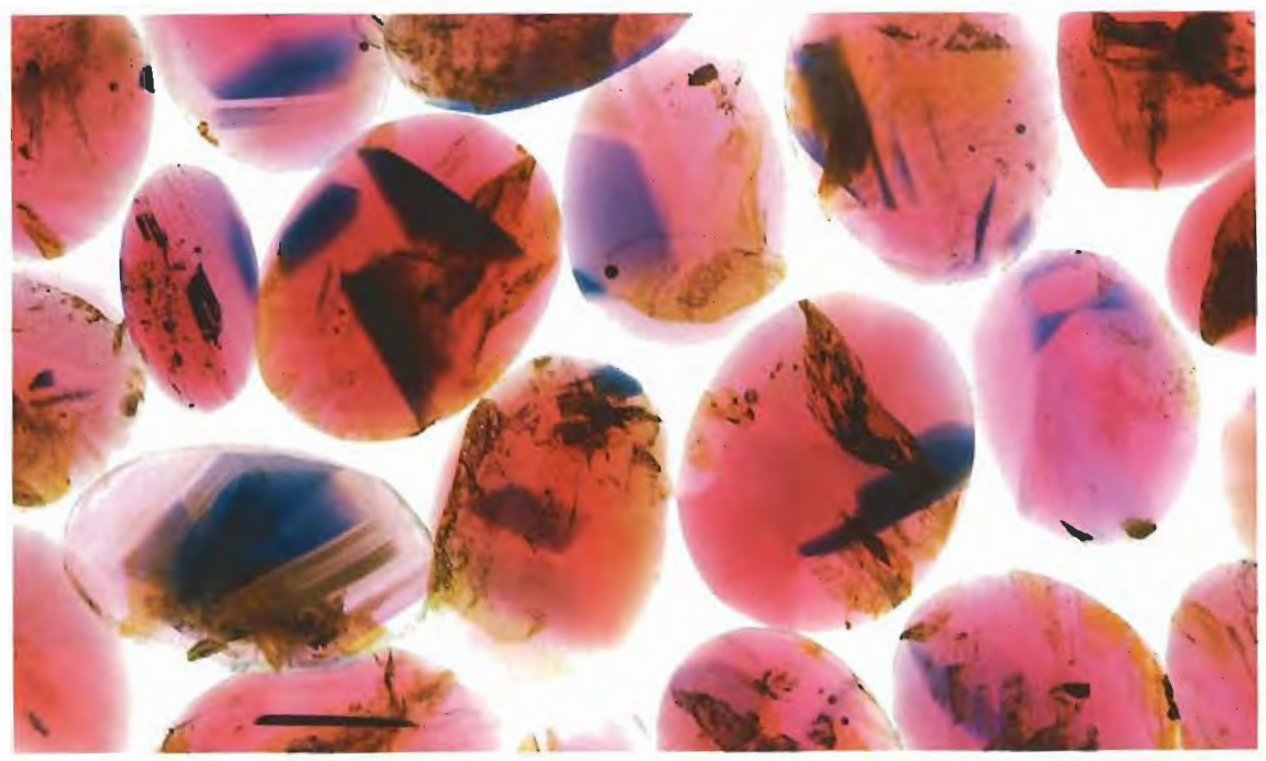

Figure 15. With immersion in methylene iodide, the numerous color zones found in these stones are easily seen. Transmitted light; photo by shane McClure.

tures (figure 16). These are commonly referred to as a "treacle" or "roiled" effect (Webster, 1983) and were once considered unique to Burmese rubies (Gübelin and Koivula, 1986). In recent years, however, such swirl-like growth features have been observed by the authors (and reported by others) in rubies from several localities other than Myanmar-e.g., India and Tanzania - to which Vietnam should now be added. The pink, orangy pink, red, blue, and colorless zones previously mentioned are frequently related to this feature.

Straight and angular parallel growth features are also quite common and at times exhibit a wedge-shaped pattern. Such growth features have been observed by the authors and reported in the literature in natural rubies from many localities, such as Tanzania (Hänni and Schmetzer, 1991) and Myanmar. Care should be taken not to confuse these with similar-appearing features in fluxgrown synthetic rubies (Kane, 1983).

Further research is being done on these growth features, and the results will be presented in a forthcoming article.

Twinning. Curiously, a structural feature that is most commonly associated with Thai rubies was also frequently observed: abundant well-developed laminated twinning planes (figure 17). In many of the samples, thin, closely spaced twinning occurs throughout the entire stone. Other stones have more widely spaced, polysynthetic twinning; at some angles of observation, we noted different pleochroic colors from the adjacent, widely spaced twinning planes (figure 18). In most of the stones

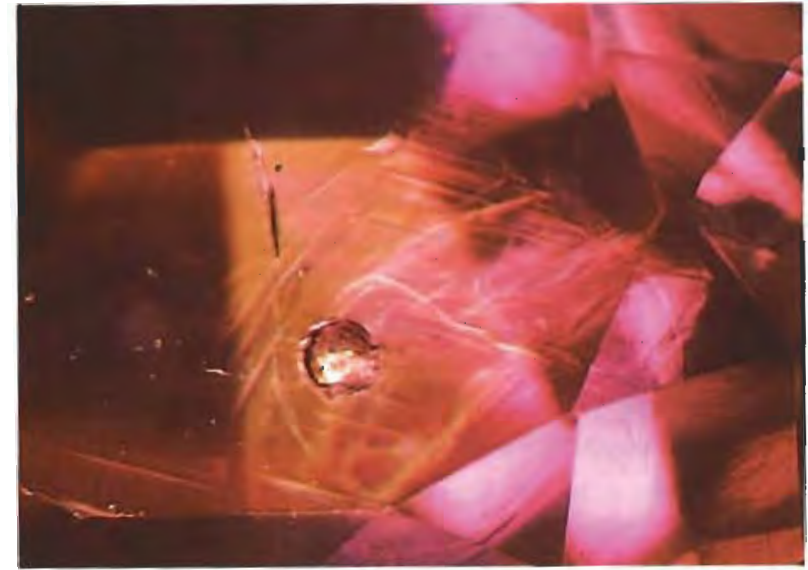

Figure 16. The swirl-like "treacle" or "roiled" effect that is frequently observed in Burmese rubies and fancy sapphires was also quite common in the Vietnamese stones examined. Darkfield, shadowing, and oblique fiber-optic illumination, magnified $30 \times$; photomicrograph by Robert E. Kane.

where this feature is present, the twinning runs in one direction only. In a minority of the stones examined, the twinning planes run in two directions and intersect. Other investigators have also noted this feature in Vietnamese stones (see, e.g., Henn and Bank, 1990; Hughes and Sersen, 1991; Brown and Chill, 1991).

Inclusions. To those who find the study of inclusions interesting, these rubies and fancy sapphires will be desirable for that reason alone. Although 


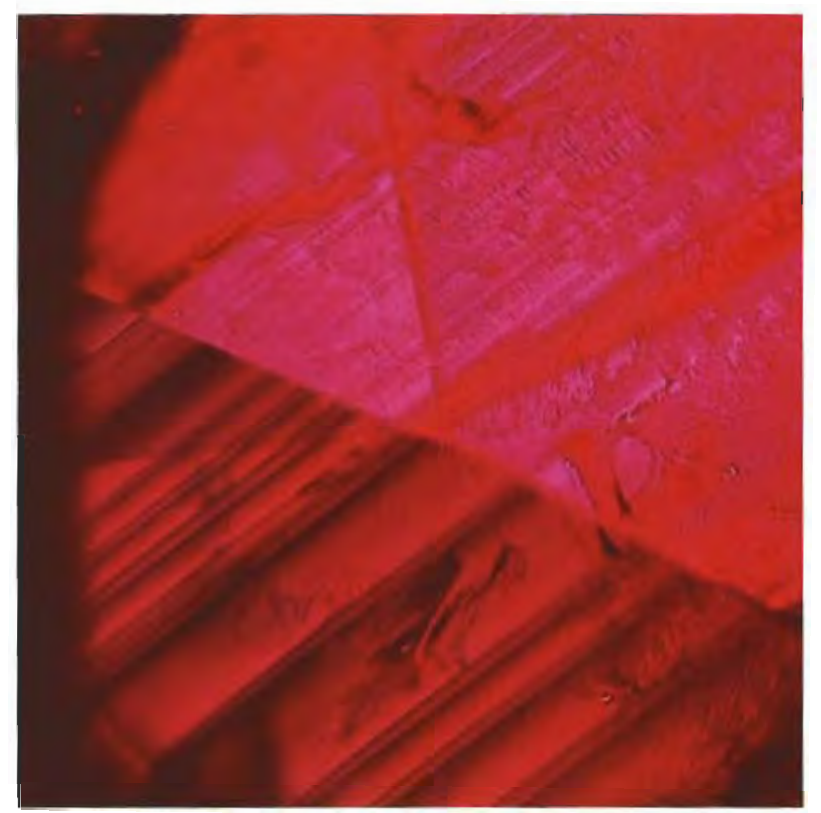

Figure 17. Laminated twinning was observed in many of the Vietnamese corundums. Polarized light, magnified $35 x$; photomicrograph by Robert E. Kane.

some of the inclusions and growth features observed in these Vietnamese stones closely resemble those found in corundums from other deposits, there are some that the authors have not encountered before.

The most common such inclusions are two types of "clouds." One type is irregular to angular in outline and is composed of minute whitish particles dispersed fairly evenly throughout the

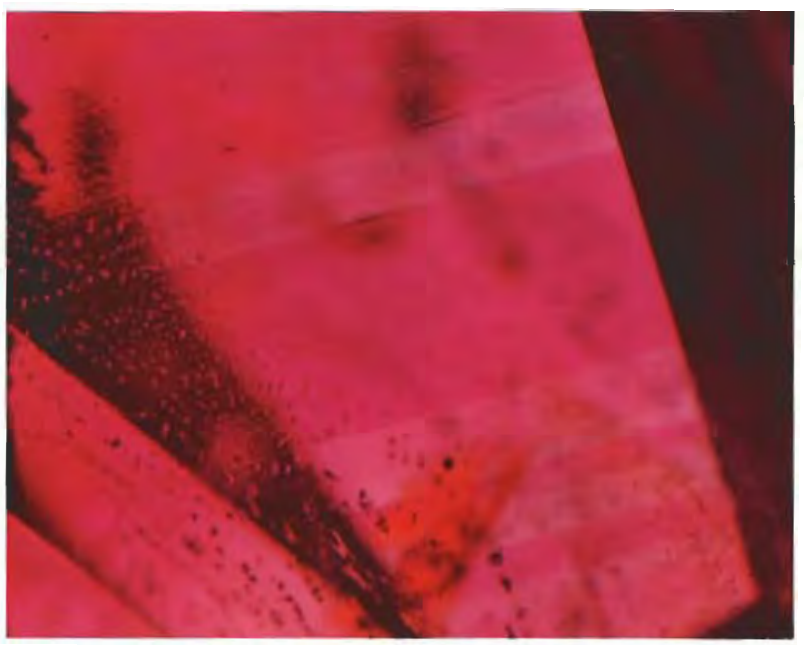

Figure 18. What appears at first glance in this photo to be color zoning is actually the effect of differences in pleochroic colors between adiacent widely spaced (polysynthetic) twinning plones. Diffused transmitted illumination, magnified 25x; photomicrograph by Robert E. Kane.

cloud. Typically, the cloud appears to have a bluish cast, perhaps the result of a light-scattering effect. Although this bluish cast may be visible with darkfield illumination, it is extremely prominent when a fiber-optic light source is used. These clouds often correlate directly with the pink, yellow, or near-colorless areas that are usually associated with irregular (swirl-like) growth zones, as seen with diffused transmitted illumination (figure 19).

The second type of cloud, consisting of larger

Figure 19. Left: Distinctly bluish clouds were frequently encountered, although oblique fiber-optic illumination (as here) was usually necessary to see them. Right: These clouds were often observed in conjunction with red, pink, and near-colorless zones, as seen here in diffused transmitted light. Magnified $25 \times$; photomicrographs by Robert E. Kane.
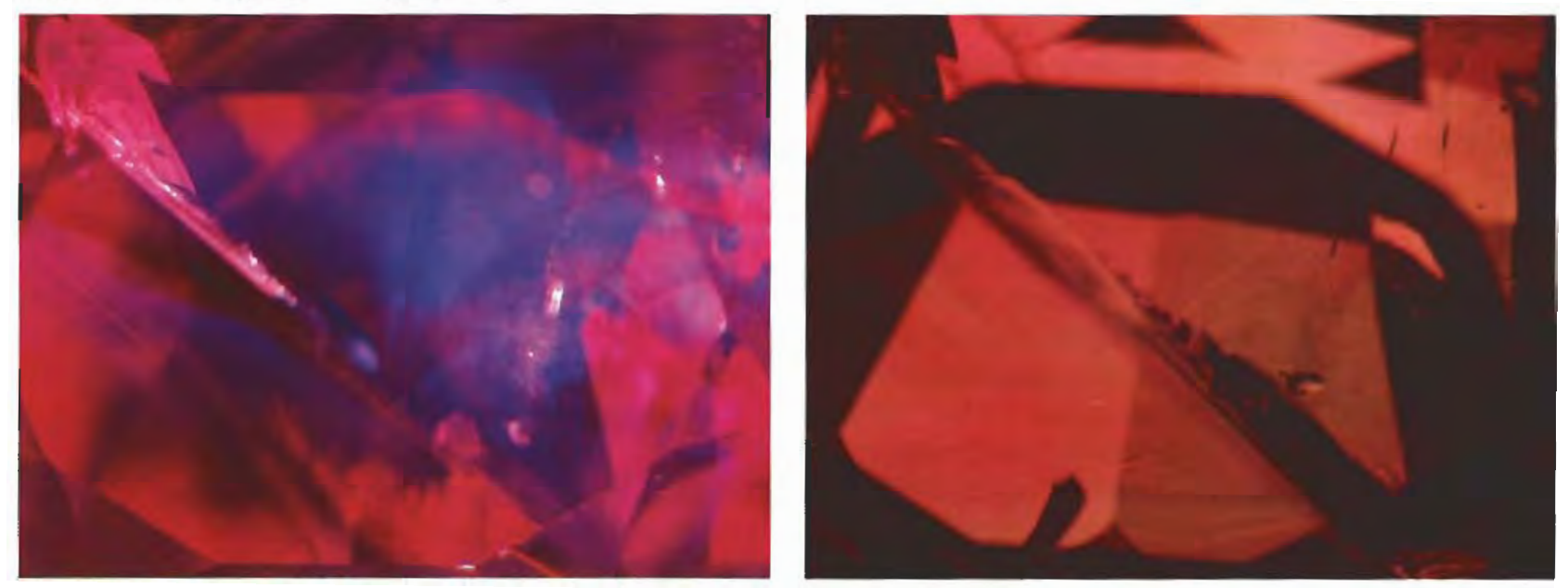


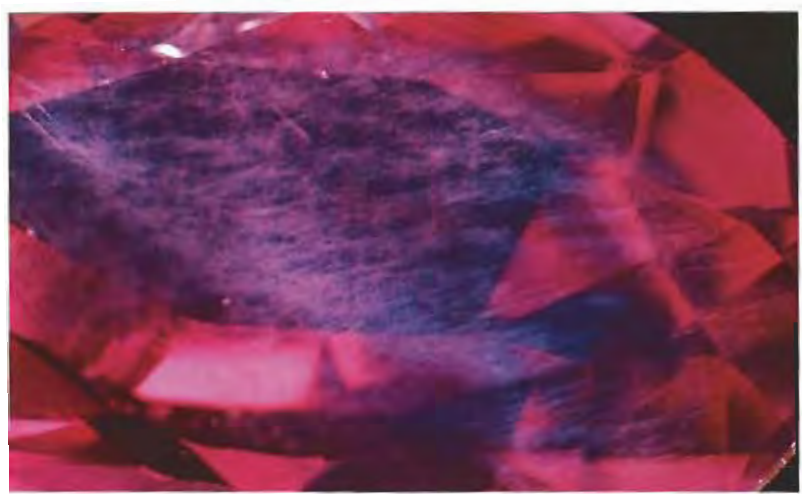

Figure 20. Irregular, whitish clouds that are somewhat wispy in appearance were often observed confined to straight growth planes in the stones in this test sample. Oblique fiber-optic illumination, magnified $20 \times$; photomicrograph by Robert E. Kane.

whitish particles, has a less distinct outline and areas of varying density that give it a wispy appearance (figure 20). This type of cloud, which is typically confined to straight growth planes, may occur in small, often planar clusters or dominating large areas of a stone. When some of these clouds were examined with high magnification (above $50 \times$ l, it was readily apparent that they are composed of tiny, acicular (needle-like), parallel inclusions of various lengths, probably rutile. Similar "needles" and minute to small particles have previously been identified as rutile in corundum from various localities.

We did not observe, in any of the stones, features that resemble the longer, acicular or shorter, wedge-shaped rutile needles that are most commonly associated with rubies and pink sapphires from Sri Lanka and Myanmar.

We did, however, see another type of acicular inclusion: very long, relatively coarse "needles" along the junctions of laminated twinning planes (figure 21). In both appearance and position relative to the twinning planes, they resembled the boehmite inclusions frequently seen in rubies from Thailand (Gübelin and Koivula, 1986) and many other sources. However, they were observed in relatively few of the Vietnamese stones and were less abundant within an individual stone than is typical of rubies from Thailand. (Note that Hughes and Sersen [1991] also report the presence in Vietnamese rubies of boehmite at crossing twin lamellae, although they do not indicate how they confirmed the identity of the inclusion.)

Partially healed fractures, planes of liquid inclusions, and two-phase inclusions were also

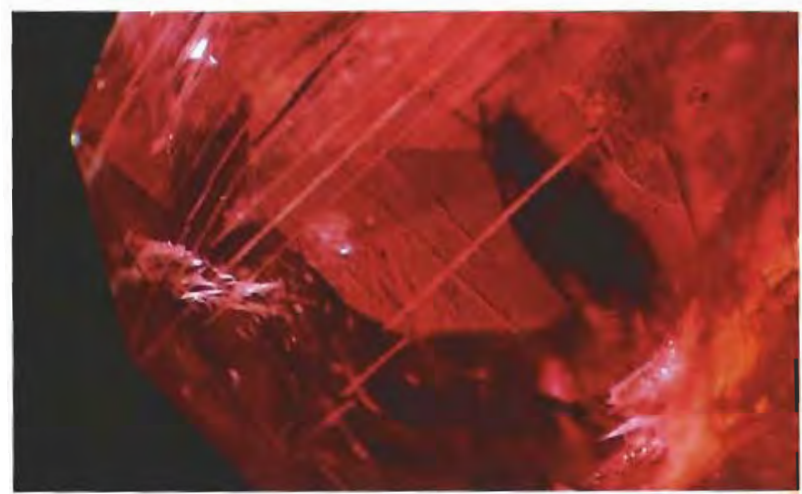

Figure 21. Needle-like inclusions of what are probably boehmite were observed in some stones along the junctions of laminated twinning planes. Oblique fiber-optic illumination, magnified $30 \times$; photomicrograph by Robert E. Kane.

commonly seen in this Vietnamese material, as they are in rubies from most localities.

Fractures, in fact, are perhaps the most common feature of the Vietnamese stones examined, and many stones had several of significant size. Interestingly, virtually all of these fractures contained bright yellowish orange to reddish orange staining (figure 22), most likely an iron oxide or

Figure 22. Orange staining was observed in nearly all of the numerous fractures present throughout this sampling of Vietnamese corundums. Darkfield illumination, magnified $25 \times$; photomicrograph by Robert E. Kane.

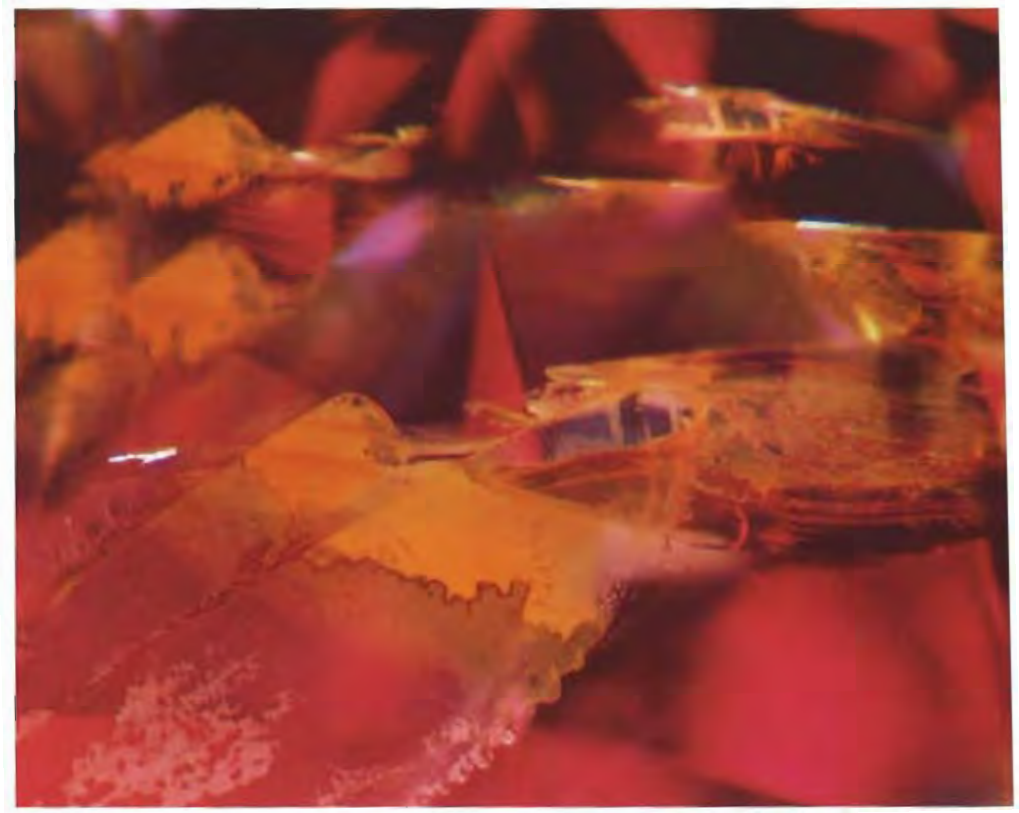




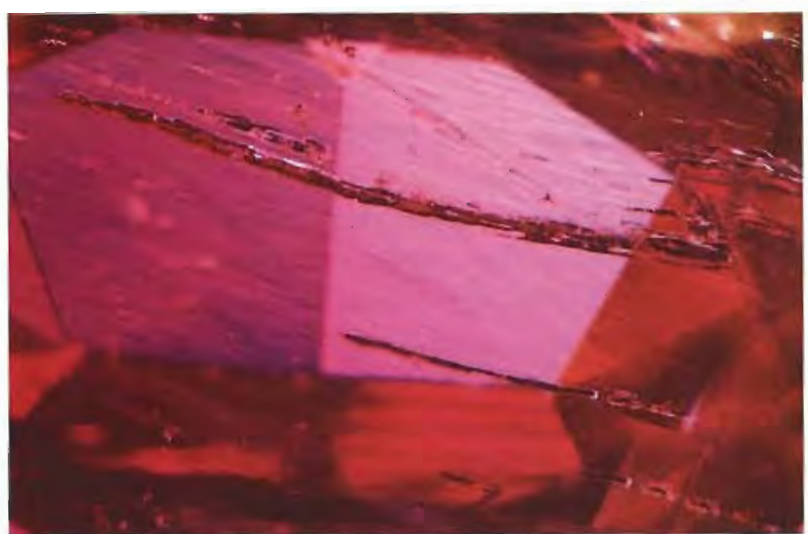

Figure 26. Black-appearing rod-like inclusions were also noted in some stones. These unusual inclusions are pyrrhotite, an iron sulfide. Darkfield illumination, magnified $35 \times$; photomicrograph by Robert E. Kane.

that they are actually brassy yellow with a metallic luster. They were proved to be pyrrhotite.

Several stones had very unusual clusters of bright orange prismatic inclusions (figure 27). These very distinctive crystals were identified as rutile (again by $\mathrm{X}$-ray diffraction). Peretti and Boehm previously identified crystals of rutile in Vietnamese rubies with microprobe analysis (as reported in Weldon, 1991).

At least 10 of the stones in this study contained irregular masses of a translucent yellowish orange material. These masses displayed no recognizable crystal form, were slightly fibrous to granular in appearance, and looked more like a secondary filling material than a primary inclusion (figure 28). X-ray diffraction produced a pattern that

Figure 27. Several stones exhibited clusters of bright orange crystals that were proved to be rutile. Oblique fiber-optic illumination, magnified $30 \times$; photomicrograph by Robert E. Kane.

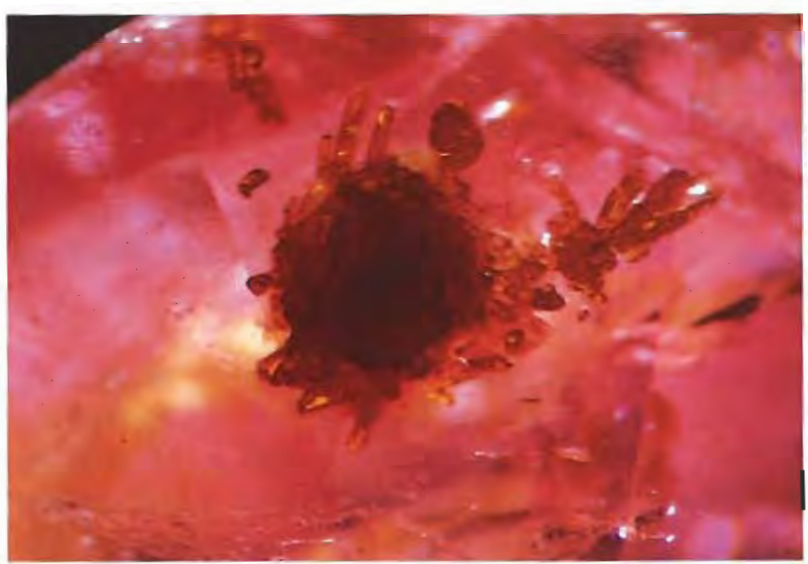

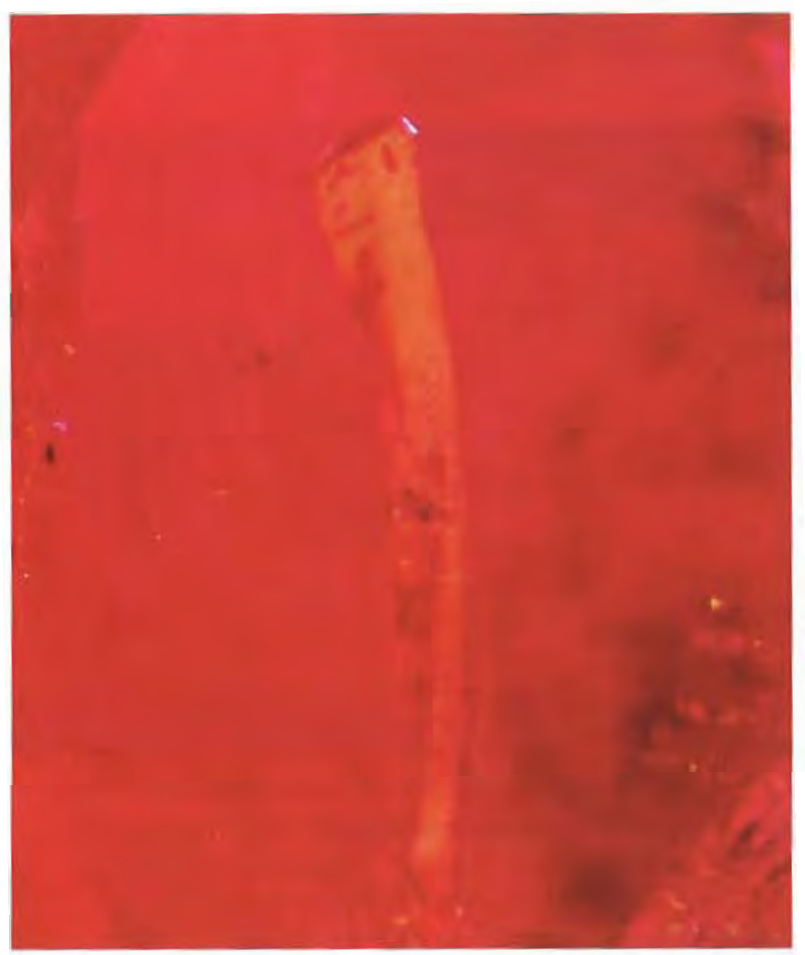

Figure 28. This unusual yellowish orange inclusion, consisting of the rare mineral nordstrandite, may be confused with fux found in Ramaura synthetic rubies. Darkfield and oblique fiber-optic illumination, magnified $30 \times$; photomicrograph by Robert E. Kane.

matched published values for the rare aluminum hydroxide nordstrandite $\left[\mathrm{Al}(\mathrm{OH})_{3}\right]$. Comparison of our relatively weak pattern to a pattern obtained from a known sample of nordstrandite from Quebec, Canada, by Dr. Anthony Kampf of the Los Angeles County Natural History Museum showed an exact match.

Nordstrandite is a rarely encountered mineral that is trimorphous with gibbsite and bayerite. It was first described when produced synthetically in 1956 by Robert A. Van Nordstrand of Sinclair Research Laboratories in Illinois (Chao and Baker, 1982). Not until 1962 was it reported to occur naturally in Sarawak, Borneo, and in Guam, in both cases associated with limestone deposits (Wall et al., 1962). Since then it has been reported from other localities around the world, frequently as a secondary solution mineral filling cavities and fissures in limestone. On several occasions, it has been associated with syenite /Chao and Baker, 1982; Petersen et al., 1976). The authors could find no reference to nordstrandite previously being reported as an inclusion in gem corundum.

This inclusion should be of special concern to 


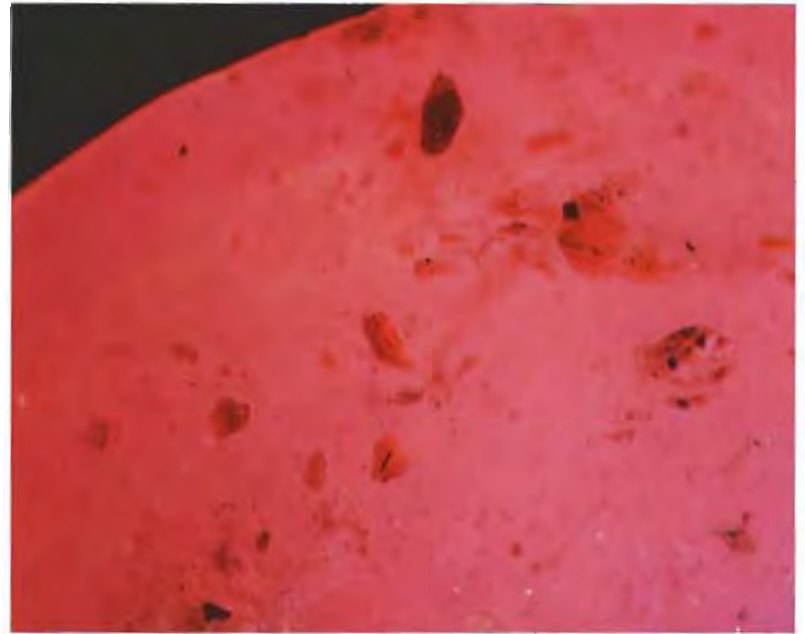

Figure 29. Brownish orange crystals of phlogopite mica were among the many solid inclusions found in these Vietnamese stones. Darkfield and oblique fiber-optic illumination, magnified $35 x$; photomicrograph by Robert E. Kane.

gemologists because it is very similar in appearance to the orange flux found in Ramaura synthetic rubies (Kane, 1983). However, the fibrous to granular appearance and yellower color of the nordstrandite inclusions should be sufficient to distinguish them from the crackled appearance

Figure 30. One sample was found to have been repaired. Note the glue layer and the misalignment of the reattached portion. Magnified 30x; photomicrograph by John I. Koivula.

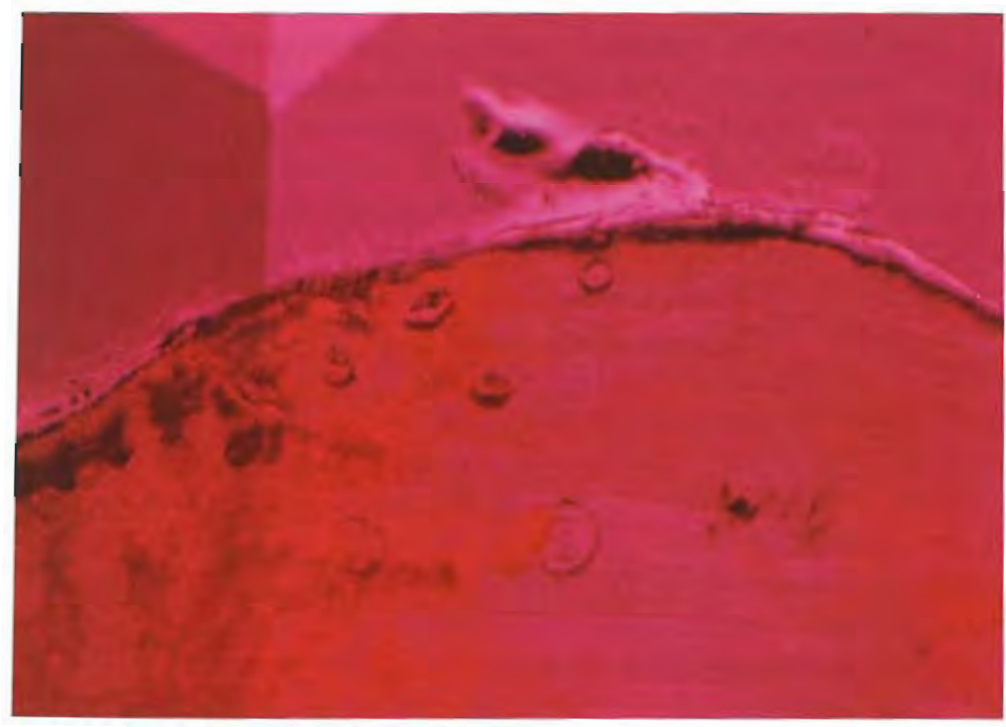

and more orange color typical of the flux in the Ramaura synthetics.

Also noted were transparent, brownish orange tabular crystals that appear somewhat rounded (figure 29). X-ray diffraction identified these as phlogopite mica. Other solid inclusions were observed in various forms and colors, but most have not yet been conclusively identified. There are some hexagonal platelets that are most likely hematite, but none in the stones we examined reached the surface.

Interestingly, one stone in the sample group was found to have been repaired. The bottom half of the pavilion had apparently separated along a fracture after faceting and was subsequently glued back on. The glue layer was easily seen, and the reattached portion was slightly misaligned (figure $30)$.

Chemical Analysis. The average chemical compositions of three samples, representative in color of the ruby and pink-purple sapphire from Luc Yen and purchased in Vietnam prior to the discovery of the Quy Chau deposits, were obtained by electron microprobe analysis at the California Institute of Technology (Paul Carpenter, analyst). These samples contain chromium as the most abundant minor element $\left(0.19\right.$ to 2.08 wt. $\left.\% \mathrm{Cr}_{2} \mathrm{O}_{3}\right)$, followed by smaller amounts of titanium $(0.01$ to $0.23 \mathrm{wt} . \%$ $\left.\mathrm{TiO}_{2}\right)$, iron $(0.01$ to $0.04 \mathrm{wt} . \% \mathrm{FeO})$, and vanadium $\left(0\right.$ to 0.03 wt. $\left.\% \mathrm{~V}_{2} \mathrm{O}_{3}\right)$. Small amounts of $\mathrm{Zn}$ and $\mathrm{Ga}$ were also found. These minor elements are all found in gem corundums from numerous localities. These results have been generally confirmed by Sam Muhlmeister and Bertrand Devouard during an ongoing study in GIA Research on the quantitative chemical analysis of rubies by energy-dispersive X-ray fluorescence (EDXRF; Muhlmeister and Devouard, in press). Slightly higher Fe content $(0.02-0.30$ wt.\% FeO) has been found by these researchers in some purplish red stones from Vietnam. The Vietnamese rubies we have analyzed by both methods show low Fe contents, similar to those in Burmese material but lower than the Fe contents in rubies from Thailand (Tang et al., 1988).

Cutting. Experiments with a variety of cutting shapes and proportions have been performed at the Savitech cutting laboratory in Ho Chi Minh City. A variety of instruments, including a video camera, are used to study the passage of light as it is 


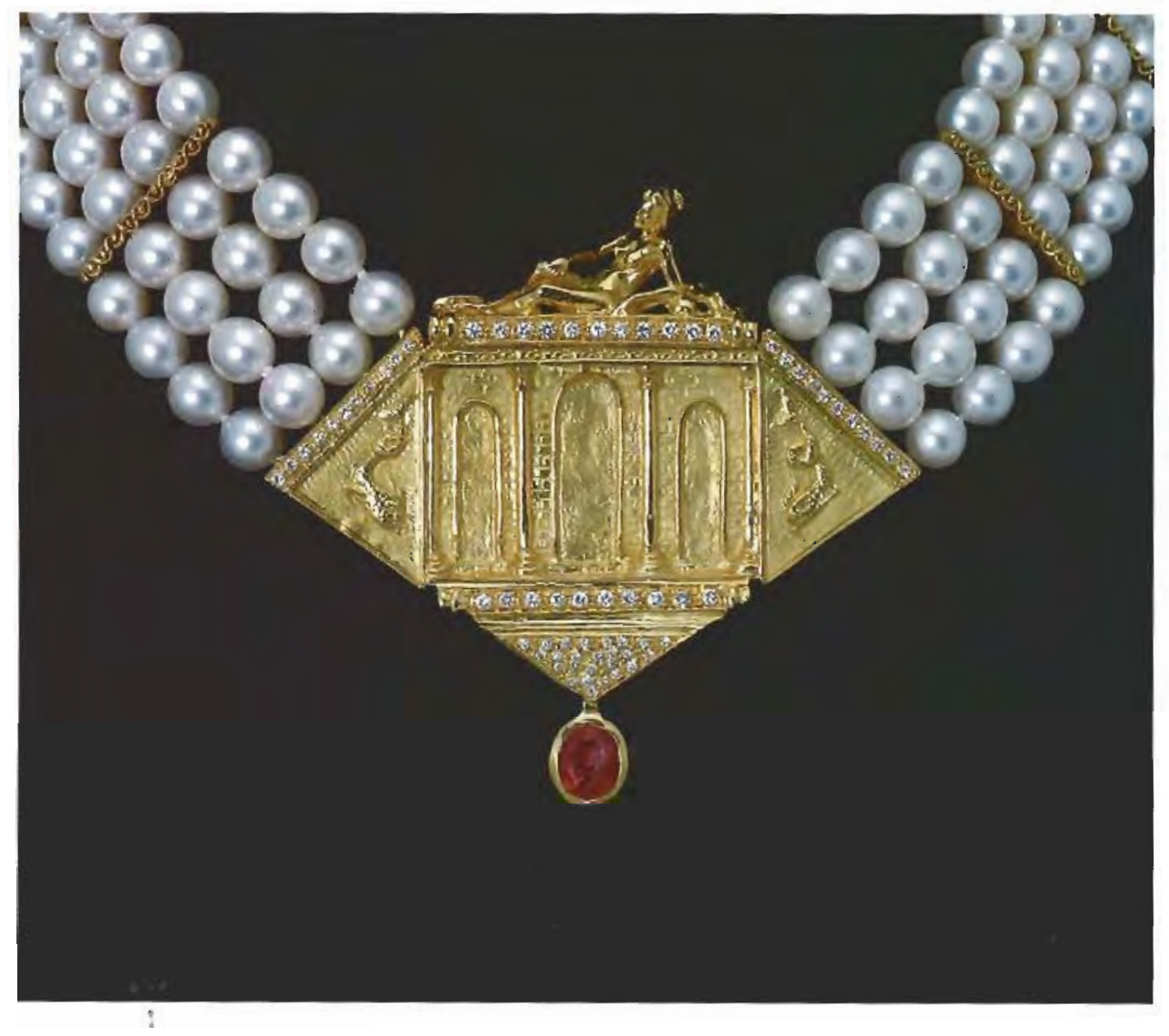

Figure 31. A number of stones have been cut in Vietnam. This Vietnamese ruby, which was cut in Ho Chi Minh City, is set in a necklace designed and manufactured by Gianni Giacoppo.

refracted inside a stone in order to determine all the variables related to shape, color, and transparency.

To date, Savitech has produced thousands of transparent faceted (figure 31) and semi-transparent cabochon-cut stones from Luc Yen and Quy Chau. Most of the stones are small, ranging from 0.5 to $1.1 \mathrm{ct}$; the largest stone cut so far by the joint venture is approximately $5 \mathrm{ct}$.

\section{OTHER GEM OCCURRENCES}

Occurrences of other gem materials have also been identified in southern and central Vietnam (again, see figure 2). Although none of these is currently being mined commercially, all show promise for the production of economic amounts in the future.

The Sapphire, Ruby, Zircon, and Garnet GemBearing Zones of Southern Vietnam. Blue and green sapphires, minor amounts of ruby, yellow and brown zircons, and pyrope garnets are widespread in alluvial or eluvial deposits on small basalt layers of various areas of southern Vietnam. Specifically, in addition to the deposits of rubies and fancy sapphires noted above, major occurrences of blue (figure 32) and other fancy-color sapphires have been discovered recently in the areas of Di Linh/Binh Dien (Lam Dong Province), Phan Thiet (Thuan Hai Province), and Gia Kiem (Dong Nai Province, at $\mathrm{Xa}$ Vo and Tien Col. These deposits, which range from about 1 to $4 \mathrm{~km}^{2}$, occur in the weathering crust of alkali basalts. Approximately $60 \%$ of the sapphires found thus far are green; yellow sapphires are seen only rarely. Rough sapphires as large as $50 \mathrm{ct}$ have been recovered.

Recent exploration also revealed yellow and brown zircons up to $20-25 \mathrm{~mm}$ in the Gia Kiem district, specifically at Sau Le and Gia Kiem. And beautiful red pyrope garnets up to $20-30 \mathrm{~mm}$ have been found at Bien Ho (Gia Lai-Kon Tum Province).

The Xuan Le Topaz-Beryl Zones of Central Vietnam. Aquamarine and colorless topaz have been found in Quaternary sediments in an area of the Thuong Xuan region (Thanh Hoa Province) that is estimated to be $1,200 \mathrm{~km}^{2}$. These gem minerals are probably related to pegmatite bodies that intrude acidic volcanic rocks and Triassic sedimentary rocks.

In addition, minor amounts of aquamarine and other beryls, as well as amethyst and smoky quartz, have been found throughout Vietnam. 
gemological properties of the Vietnamese rubies and pink to purple sapphires are consistent with those of rubies and fancy sapphires from Mogok and other marble-type localities. Notable internal features in the Vietnamese samples examined include distinct blue color zones, a swirled growth ("treacle") effect, wedge-shaped growth features, well-developed laminated twinning planes, "clouds" of minute (rutile?) particles, and orangestained fractures. A number of solid inclusions have been identified by X-ray diffraction analysis: calcite, apatite, pyrrhotite, phlogopite, and clusters of rutile. Irregular masses of translucent yellowish orange nordstrandite observed in some of the Vietnamese stones could cause the gemologist to confuse this material with some flux-grown synthetic rubies. It should be noted again that we have seen flame-fusion synthetic rubies that were purchased as Vietnamese rubies both in Vietnam and elsewhere.

While it is not unusual to find most of these minerals as inclusions in rubies and pink to purple sapphires, the form in which some of them occur in the stones from Vietnam is unique in the authors' experience: the rod-like habit of the pyrrhotite and some of the calcite inclusions; rutile crystals in the form of large, bright orange prisms; and the slightly bluish clouds of fine particles. We have not seen nordstrandite as an inclusion in rubies from any other locality.

The above is not meant to suggest that these inclusions, taken individually or as a suite of internal features, can be used to designate locality origin of rubies and pink to purple sapphires from Vietnam. In fact, as new sources of gem-quality ruby are discovered, we may learn that these features are not unique to material mined in Vietnam. Significantly, the recently reported deposits in southwestern China are not far from the Vietnamese border, and could conceivably be contiguous with the Vietnamese deposits (see, e.g., "Ruby Discovered in China Is Similar to Vietnamese," 1991). In addition, we have learned that rubies are currently being mined in Laos. It is quite possible, then, that many of the "Vietnamese" rubies now entering the world market are actually from any one of several deposits in Southeast Asia.

It also appears that heat-treated Vietnamese rubies have reached the market. While in-depth studies have not yet been performed on the heat 
treatment of rubies and sapphires from Vietnam, there is no reason at this time to believe that these stones will react differently from those from other geologically similar localities.

The gems described here are from the first significant gem deposits in Vietnam, and it is anticipated that they will not be the last. Discoveries of corundum and other gem materials in various regions of Vietnam suggest that this country could become a rich source as future exploration reveals additional deposits of economic significance.

\section{REFERENCES}

Arem J. (1987) Color Encyclopedia of Gemstones, 2nd ed., Van Nostrand Reinhold Co., New York.

Bank H., Henn U. (1990) Borsen Bulletin: Rubies from Vietnam. Goldschmiede und Uhrmacher Zeitung, No. 12, December, p. 106 .

Bowersox, G.W. (1985) A status report on gemstones from Afghanistan. Gems e) Gemology, Vol, 21, No, 4, pp. 192-204.

Brown G, Chill B. (1991) Vietnamese ruby. Wahroongai News, Vol. 25, No. 2, pp. 3-4.

China's ruby similar to ruby from Myanmar (1991). Jewellery News Asia, No. 85 , p. 180.

Chao G.Y., Baker J. (1982) Nordstrandite from Mont St-Hilaire, Quebec. Canadian Mineralogist, Vol. 20, part 1, pp. 77-85.

Federman D. (1991) Gem profile: Vietnamese ruby. Modern Jeweler, vol. 90, No. 8, pp. 23-24.

Gübelin E.I., Koivula J.l. (1986) Photoatlas of Inclusions in Gemstones, ABC Edition, Zurich.

Hänni H.A., Schmetzer K. (1991) New rubies from the Morogoro area, Tanzania. Gems et) Gemology, Vol. 27, No. 3, pp. $156-167$.

Harding R.R., Scarratt K. (1986) A description of ruby from Nepal. Joumal of Gemmology, Vol. 20, No. 1, pp. 3-10

Henn U., Bank H. (1990) A gemological examination of ruby from Viemam. ICA Gazette, November, pp. 9-10.

Henn U., Bank H. (1991) Rubine aus Vietnam. Zeitschrift der Deutschen Gemmologischen Gesellschaft, Vol. 40, No. 1, pp. 25-28.

Hughes R.W., Sersen W.J. (1991) Bangkok gem market review: Vietnamese ruby. Gemological Digest, Vol. 3, No. 2, pp. $68-70$.

Kane R.E. (1983) The Ramaura synthetic ruby. Gems e) Gemology,Vol. 19, No. 3, pp. 130-148.

Koivula J.I., Kammerling R.C. (1990) Gem news: Rubies from Vietnam? Gems e) Gemology, Vol. 26, No. 2, pp. 163-164.

Koivula J.I., Kammerling R.C. (1991) Gen news: More on Vietnam gem finds. Gerrs $\Leftrightarrow$ Gemology, Vol. 27, No. 1, pp. $51-52$.

Liddicoat R.T. (1989) Handbook of Gen Identification, 12th ed., 2nd rev printing. Gemological Institute of America, Santa Monica, CA.
Long-awaited auction may come off in July (1991). Jewel Siam, June-July, p. 25.

Muhlmeister S., Devouard B. (in press) Trace element chemistry of natural and synthetic rubies. In A. S. Keller, Ed., Proceedings of the 1991 International Gemological Symposium, Gemological Institute of America, Santa Monica, CA.

No date for ruby auction in Vietnam (1991). Jewellery News Asia, No. 77, p. 48.

Petersen O.V., Iohnsen O., Leonardsen E.S. (1976) Nordstrandite from Narssârssuk, Greenland. Mineralogical Record, Vol. 7. No. 2, pp. 78-82.

Ruby discovered in China is similar to Vietnanese (1991). ICA Gazette, August, p. 11.

Ruby auction in Vietnam (1990). Thailand Jewellery Review, August, p. 34

Synthetic found mixed with rough ruby (1991). Jewellery News Asia, No. 85, p. 172.

Tang S.M., Tang S.H., Tay H.S., Retty A.T. (1988) Analysis of Burmese and Thai rubies by PIXE. Applied Spectroscopy, Vol. 42, No. 1, pp. 44-48.

Tien P.C., Ed. (1989) Geology of Kampuchea, Laos and Vietnam. Institute for Information and Documentation of Mines and Geology, Hanoi, Vietnam.

Vietnam: An important potential new source of fine ruby (1990). ICA Gazette, November, p. 8.

Vietnam claims major ruby find (1990). Jewelers' CircularKeystone, Vol. 161, No. 12, pp. 22, 24.

Viets delay ruby sales until ... (1991). Jewelers' CircularKeystone, Vol. 162, No. 3, p. 36 .

Wall J.R.D., Wolfenden E.B., Beard E.H., Deans T. (1962) Nordstrandite in soil from West Sarawak, Bonneo. Nature, Vol. 196, No. 4851, pp. 264-265.

Webster R. (1983) Gems: Their Sounces, Descriptions and Identification, 4th ed., Rev. by B. W. Anderson. Butterworth \& Co., London.

Weidinger W.A. (1991) Beware of deception on Vietnamese rubies. Jewelers' Circular-Keystone, Vol. 162, No. 7, p. 92.

Weldon R. (1991) Why the Vietnam reds are giving us the blues. jewelers' Circular-Keystone, Vol. 162, No. 5, pp. 46-48 